\title{
IMPLEMENTASI THE NEW FRAUD TRIANGLE MODEL DENGAN PERSPEKTIF SYARIAH DALAM MENDETEKSI PERILAKU FRAUD
}

\author{
Agung Budi Sulistiyo \\ agungbudi.feb@unej.ac.id \\ Riza Dewi Al Ardi \\ Ahmad Roziq \\ Universitas Jember, Indonesia
}

\begin{abstract}
This research aims to explore deeply how the concept of the new fraud triangle model with sharia perspectives can be used to detect fraud behaviour in sharia banks with a case study approach. This research was conducted on one of the sharia banks in East Java. Through in-depth interviews with fraud actors, actors and internal auditors and supported by the results of observations in the field and the study of documentary evidence, the study succeeded in revealing some important findings. The findings suggest that; (1) fraud action committed due to the lifestyle of the perpetrator who exceeds the income received; (2) utilize the job position to commit fraud; (3) fraud action that occurs as a result of the opportunity. (4) the act of fraud also occurs because of the personal integrity that is not good from the perpetrator. The implications of this study are expected to contribute to developing science and information on the importance of management of risk management and strengthening of internal control systems for Sharia Financial Institutions (SFI) in attempts to reveal fraud.
\end{abstract}

Key words: the new fraud triangle model; sharia perspectives; fraud behaviour

\begin{abstract}
ABSTRAK
Penelitian ini bertujuan untuk mengkaji secara mendalam bagaimana konsep the new fraud triangle model dengan perspektif syariah dapat digunakan untuk mendeteksi perilaku fraud pada bank syariah dengan pendekatan studi kasus. Penelitian ini dilakukan pada salah satu bank syariah di Jawa Timur. Melalui wawancara mendalam dengan pelaku fraud, atasan pelaku dan auditor internal serta didukung dengan hasil observasi di lapangan dan studi dokumentasi bukti fraud, penelitian ini berhasil mengungkap beberapa temuan yang penting. Temuan tersebut menunjukkan bahwa; (1) tindakan fraud yang dilakukan dikarenakan gaya hidup pelaku yang melebihi dari penghasilan yang diterima; (2) memanfaatkan posisi pekerjaan yang dimiliki untuk melakukan fraud; (3) tindakan fraud yang terjadi diakibatkan oleh adanya peluang yang dimiliki. (4) tindak kecurangan juga terjadi karena personal integrity yang tidak baik dari pelaku. Implikasi dari penelitian ini diharapkan dapat memberikan kontribusi untuk mengembangkan ilmu pengetahuan dan informasi tentang pentingnya manajemen pengelolaan resiko dan penguatan sistem pengendalian intern bagi Lembaga Keuangan Syariah (LKS) dalam upaya mengungkapkan fraud.
\end{abstract}

Kata kunci: the new fraud triangle model; perspektif syariah; perilaku fraud

\section{PENDAHULUAN}

Secara umum perbankan syariah di Indonesia muncul karena adanya beberapa elemen masyarakat yang tidak sepakat dengan prinsip operasional bank konvensional (Sayekti dan Mauleny, 2013; Mukhlishin dan Suhendri, 2018). Hal ini dikarenakan beberapa pihak tersebut menganggap bahwa prinsip dari bank konvensional mengandung unsur riba yang tidak sesuai dengan syariat Islam. Sejalan dengan hal tersebut Hidayati (2008) menyatakan beberapa keberatan mendasar terhadap sistem perbankan konvensional juga diyakini mempe- 
ngaruhi perkembangan Lembaga Keuangan Syariah, antara lain, pertama, struktur akad yang menggunakan sistem bunga dianggap sama atau menyerupai riba dan kedua, ketiadaan jaminan tentang kehalalan dan cara pengelolaan atas aktivitas investasi pada bank konvensional.

Bank syariah sebagai lembaga yang mengelola keuangan masyarakat berbasis syariah beserta lembaga keuangan syariah diharapkan mampu menjaga serta mengelola transaksi mereka sesuai dengan hukum Islam. Dengan demikian, bank syariah diharapkan mampu menjadi alternatif bagi beberapa pihak yang tidak sesuai dengan prinsip bank konvensional. Harapan dari masyarakat terhadap bank syariah yang dapat menjalankan usahanya dengan prinsip syariah dan sesuai dengan ajaran Islam pada kenyataannya tidak selalu berjalan mulus. Hal ini dikarenakan pada dasarnya pada perkembangan dalam dunia perbankan selalu tidak terlepas dari tindakan kecurangan (Meliana dan Hartono, 2019). Surat Edaran Bank Indonesia No.13/28/DPNP tahun 2011 menjelaskan bahwa fraud adalah tindakan yang menyimpang atau membiarkan secara sengaja dengan tujuan untuk mengelabui, menipu, atau memanipulasi yang menyebabkan kerugian baik pada pihak bank, nasabah atau pihak lain secara langsung maupun tidak. Oleh karena itu, tindakan fraud merupakan tindakan kriminal yang melanggar hukum.

Tindakan fraud yang terjadi pada bank bisa dilakukan dalam berbagai bentuk. Rustiarini et al. (2017) menjelaskan bahwa fraud yang terjadi pada perbankan adalah terkait dengan pemberian kredit (43\%), melakukan manipulasi (19.6\%), dan pemalsuan (18.6\%). Tindakan fraud yang terjadi pada dunia bisnis dapat dilakukan oleh individu maupun kelompok (Kurrohman, 2010). Tindakan fraud juga bisa terjadi pada level karyawan atau pada level manajer. Setiap tindakan fraud yang dilakukan oleh pelaku pada setiap level akan memberikan gejala yang berbeda. Tindakan fraud yang dilakukan oleh pelaku pada level karyawan akan memberikan gejala (red flags) yaitu adanya transaksi yang tidak normal. Contohnya yaitu seperti pengeluaran tanpa dokumen pendukung, kesalahan pencatatan, tidak adanya bukti transaksi, dan lainnya. Selanjutnya, tindakan fraud yang dilakukan oleh pelaku pada level manajemen akan memberikan gejala yang lain yaitu ketidakjelasan kebijakan, turunnya motivasi karyawan, keluhan konsumen atau vendor, hilangnya kas secara terstruktur, penurunan kinerja perusahaan dan lainnya. Adanya gejala-gejala yang ditimbulkan dari terjadinya fraud ini perlu untuk diwaspadai agar dapat mendeteksi dengan segera, sehingga fraud yang telah terjadi dapat segera diketahui dan diselesaikan.

Fenomena fraud yang terjadi baik di perbankan atau non perbankan sebenarnya dapat terjadi karena adanya beberapa sebab yang mendasar. Penyebab terjadi tindakan fraud ini telah dijelaskan pada teori the new fraud triangle model. Teori ini merupakan perkembangan terbaru dari dua teori fraud sebelumnya yaitu teori fraud triangle dan teori fraud diamond. Konsep dari the new fraud triangle model adalah sebagai berikut (Wolfe dan Hermanson, 2004). Teori the new fraud triangle model menjelaskan bahwa penyebab terjadi fraud adalah motivasi, kesempatan, integritas, dan kemampuan. Unsur fraudster's capabilities dapat menimbulkan tekanan, peluang dan rasionalisasi dari seseorang untuk melakukan fraud (Wolfe dan Hermanson, 2004). Seseorang yang memiliki kemampuan (capabilities) akan mampu menentukan celah untuk bisa melakukan kecurangan dengan tingkat risiko yang sekecil mungkin agar tidak diketahui oleh pihak lain. Tuanakotta (2013:46) menjelaskan bahwa opportunity pada fraud adalah berhubungan dengan peluang dari pelaku fraud dalam melakukan kecurangan. Unsur motivasi sama halnya dengan unsur tekanan (pressure) pada teori fraud triangle dan fraud diamond. Unsur motivasi dapat dibedakan menjadi tiga yaitu yang diakibatkan oleh gaya hidup, yang diakibatkan oleh tuntutan kerja, dan dari pihak luar individu (Lister, 
2007:63). Terakhir, unsur personal integrity adalah unsur yang sama dengan unsur rasionalisasi pada teori fraud triangle dan fraud diamond. Unsur personal integrity menggambarkan bahwa pelaku fraud akan membuat suatu bentuk pembenaran atas tindakan kecurangan yang dilakukan. Vona (2008) mencontohkan mengenai rasionalisasi fraud adalah ketika manajer melakukan fraud laporan keuangan dengan alasan untuk memenuhi target margin perusahaan yang telah ditetapkan. Dengan demikian, tindakan fraud yang dilakukan manajer akan dianggap sebagai tindakan yang dapat diterima.

Secara umum dapat ditegaskan bahwa tindakan fraud dapat terjadi di berbagai macam bank baik bank konvensional ataupun bank syariah. Hal ini dikarenakan penyebab terjadinya fraud disebabkan oleh sifat-sifat dasar yang dimiliki oleh manusia. Bukti nyata dari adanya tindakan fraud pada bank syariah telah dialami oleh salah satu bank syariah terbesar di Indonesia pada tahun 2015. Pelaku yang merupakan seorang manager dan officer, bekerjasama dengan dua pelaku lain dengan cara mencairkan Surat Kredit Berdokumen Dalam Negeri (SKBDN) menggunakan jaminan berupa deposito palsu. Atas kejadian tersebut, diduga kerugian mencapai 75 miliar rupiah. Angka yang fantastis bagi seorang pegawai bank yang gaji perbulannya hanya beberapa juta saja. Diketahui, uang tersebut digunakan oleh para pelaku untuk keperluan pribadi, seperti membeli rumah, saham, dan beberapa mobil mewah. Kejadian tersebut ditemukan pertama kali oleh auditor intern bank yang sedang melaksanakan tugas audit pada unit yang bersangkutan. Selanjutnya, sang auditor melaporkan dan memproses kasus tersebut ke Mabes Polri. Atas kejadian itu, Pengadilan Negeri Jakarta Selatan menjatuhkan hukuman pidana dan denda kepada kedua pelaku yang tak lain merupakan pegawai bank itu sendiri (Kartika, 2015). Berita fraud tersebut ternyata bukan merupakan kasus pertama yang menimpa sebuah bank syariah terbesar di Indonesia. Sebelumnya, bank tersebut juga pernah kebobolan. Dengan modus penyaluran kredit fiktif bagi beberapa nasabah, seorang kepala cabang, kepala kantor cabang pembantu, serta account officer juga melakukan fraud dengan taksiran kerugian mencapai 59 miliar rupiah. Kasus ini terbongkar setelah auditor intern mencurigai adanya kejanggalan atas penyaluran dana tersebut (Republika, 2013). Selain itu, kasus fraud serupa juga pernah menimpa salah satu cabang dari bank syariah yang serupa di Jawa Timur. Kasus tersebut melibatkan seorang pegawai frontliner serta atasan langsungnya. Sebagaimana kasus-kasus sebelumnya, kasus ini pertama kali ditemukan oleh auditor internal yang sedang bertugas melakukan audit pada unit tersebut. Auditor tersebut awalnya mencurigai transaksi pemindahbukuan dari rekening salah satu nasabah kepada rekening pegawai frontliner tersebut. Perlu diketahui sebelumnya, bahwa seorang frontliner tidak diperbolehkan untuk melakukan transaksi apapun atas rekening pribadinya dengan menggunakan user yang bersangkutan. Hal ini dilakukan untuk meminimalisir upaya fraud. Namun pada kasus ini, pelaku justru melakukan transaksi tersebut dengan menggunakan user pribadinya. Dan transaksi tersebut juga telah diotorisasi oleh atasan langsung dari pelaku.

Penemuan fraud yang menimpa perusahaan yang bergerak di bidang syariah ini, menimbulkan pertanyaan bagi sebagian besar penduduk Indonesia, terutama para nasabahnya. Hal ini dikarenakan bank syariah merupakan bank yang bekerja dengan berlandaskan pada prinsip syariah, namun pada kenyataannya karyawan lembaga keuangan yang bergerak di bidang syariah melakukan tindakan fraud yang merupakan berbagai pihak. Penelitian ini dilakukan dengan tujuan untuk mengetahui bagaimana terjadinya fenomena fraud yang terjadi pada salah satu bank syariah terbesar di Indonesia ini. Penelitian ini dilakukan 
dengan berdasarkan pada teori the new fraud triangle model dalam perspektif syariah untuk menjelaskan fenomena fraud yang terjadi. Teori ini dipilih sebagai dasar teori pada penelitian ini dikarenakan teori ini merupakan perkembangan teori fraud yang paling baru dari dua teori sebelumnya yaitu fraud triangle dan fraud diamond.

Penelitian terkait penerapan teori fraud dalam menjelaskan tindakan fraud pada perbankan juga sebelumnya telah dilakukan oleh penelitian-penelitian sebelumnya. Hasil penelitian dari Rustiarini et al. (2016) menemukan bahwa kemampuan (capabilities) menjadi dimensi paling tinggi dalam mendeteksi fraud pada laporan keuangan pada Bank Perkreditan Rakyat (BPR). Hasil penelitian dari Wahyuningtyas (2016) menyatakan bahwa empat dimensi dari fraud diamond seperti tekanan, kesempatan, rasionalisasi, dan kabapibilitas mampu menjelaskan terjadinya kecurangan laporan keuangan pada perusahaan perbankan. Hasil penelitian dari Yesiariani dan Rahayu (2017) menemukan bahwa variabel external pressure dan rationalization terbukti secara signifikan berpengaruh positif dalam mendeteksi financial statement fraud pada perusahaan go public di Bursa Efek Indonesia (BEI) dalam indeks LQ-45 untuk periode 2010-2014.

Penjelasan terkait penelitian-penelitian sebelumnya menunjukkan bahwa penelitian yang dilakukan masih menggunakan dasar teori fraud diamond dalam menjelaskan tindakan fraud yang terjadi (Ristianingsih, 2017; Wahyuningtyas, 2016; Nugraheni dan Triatmoko, 2017). Selain itu, penelitianpenelitian sebelumnya juga masih belum menggunakan bank syariah sebagai objek penelitian serta sebagian besar menggunakan metode kuantitatif. Oleh karena itu, penelitian ini akan melakukan pembaharuan terkait model penelitian sebelumnya yang telah melakukan penelitian terkait penerapan teori fraud untuk menjelaskan fenomena fraud. Keterbaruan pertama yaitu terletak pada objek yang diteliti, dimana objek yang digunakan pada penelitian ini adalah bank syariah. Keterbaruan kedua yaitu terletak pada teori yang dipakai, penelitian ini mengaplikasikan teori the new fraud triangle model. Keterbaruan ketiga, penelitian ini menggunakan metode kualitatif dalam menjawab masalah penelitian.

Latar belakang penelitian telah menunjukkan bahwa fenomena fraud yang terjadi pada perbankan syariah dapat dijelaskan melalui konsep the new fraud triangel model. Dengan demikian, rumusan masalah yang ingin dijawab pada penelitian ini adalah bagaimanakah implementasi konsep the new fraud triangle model dapat digunakan untuk mendeteksi perilaku fraud pada bank syariah? Adapun tujuan penelitian ini untuk mengkaji secara implementasi konsep the new fraud triangle model dalam mendeteksi perilaku fraud pada bank syariah.

\section{TINJAUAN TEORETIS}

\section{New Fraud Triangle Model}

Kassem dan Higson (2012) mengklasifikasikan faktor penyebab terjadinya fraud, yang berbeda dengan teori fraud triangle yang dicetuskan oleh Cressey (1950). Dengan meninjau beberapa literatur sebelumnya, tentang teori fraud, Kassem dan Higson (2012) menyimpulkan bahwa sebagian peneliti mengklasifikasikan faktor penyebab fraud terjadi karena pribadi, pekerjaan, atau tekanan eksternal. Tipikal pekerjaan yang melakukan fraud juga bisa terjadi pada karyawan maupun manajemen (Sujeewa et.al, 2018; Said et.al, 2017; Zuberi dan Mzenzi, 2019). Sementara penelitian yang lain mengklasifikasikan faktor penyebab fraud adalah karena faktor keuangan dan non-keuangan. Namun, kedua klasifikasi tersebut sebenarnya saling berkaitan. Misalnya, tekanan pribadi, dapat terjadi karena tekanan finansial ataupun non-finansial.

Dengan cara yang sama, tekanan pekerjaan juga dapat terjadi karena faktor finansial dan non-finansial. Dengan demikian, Kassem dan Higson (2012) mengingatkan auditor eksternal bahwa tekanan atau motif untuk melakukan fraud dapat berupa 
tekanan pribadi, pekerjaan, maupun tekanan eksternal, dan masing-masing jenis tekanan ini juga dapat terjadi karena faktor finansial maupun non-finansial. Kassem dan Higson (2012) juga berpendapat bahwa semua teori fraud sebelumnya, merupakan perluasan dari teori segitiga fraud, dan harus diintegrasikan dalam satu model yang selanjutnya lebih dikenal sebagai the new fraud triangle model, yang mencakup motivasi, kesempatan, integritas, dan kemampuan.

\section{Fraud dalam Perspektif Islam}

Dalam perspektif Islam, istilah fraud tidak hanya ditujukan bagi kejahatan yang dilakukan oleh penjahat berkerah putih saja. Lebih dalam lagi, Islam menyebutkan bahwa tadlis (penipuan) dan taghrir atau gharar (ketidak pastian) dalam sebuah transaksi jual beli, juga merupakan bagian dari fraud (Alfian, 2016). Artinya, tidak hanya seseorang yang bekerja pada perusahaan orang lain saja, yang dianggap memiliki kemungkinan untuk melakukan fraud. Akan tetapi, seseorang yang berprofesi sebagai pedagang pun, memiliki kemungkinan melakukan fraud jika dalam perniagaannya terdapat unsur tadlis maupun taghrir. Dalam Al Qur'an, Allah bersabda:

"Celakalah bagi orang-orang yang curang (dalam menakar dan menimbang). (Yaitu) orang-orang yang apabila menerima takaran dari orang lain mereka minta dicukupkan. Dan apabila mereka menakar atau menimbang (untuk orang lain), mereka mengurangi." (Terjemahan QS Al Muthaffifiin : 1-3).

"Dan janganlah kamu makan harta di antara kamu dengan jalan yang batil dan (janganlah) kamu menyuap dengan harta itu kepada para hakim dengan maksud agar kamu dapat memakan sebagian harta orang lain itu dengan jalan dosa, padahal kamu mengetahui." (Terjemahan QS. Al - Baqarah : 188).
Berdasarkan ayat di atas, Islam mengutuk mereka yang berbuat curang dengan hukuman yang berat. Diantara mereka adalah orang yang mengurangi takaran atau timbangan. Islam menyebutkan bahwa tindakan mengurangi takaran atau timbangan dalam sebuah transaksi jual beli, juga merupakan sebuah fraud (Rahman, 2018; Fauziah, 2019).

Dalam sebuah riwayat, Nabi Muhammad juga melarang penjual untuk menyembunyikan kecacatan atas barang yang dijualnya. Tindakan menyembunyikan kekurangan atau kecacatan oleh penjual dapat menyebabkan munculnya penipuan dan ketidakadilan. Itulah sebabnya, Nabi Muhammad mencontohkan untuk mengungkapkan kekurangan dari apa yang dijual, serta mengatakan kebenaran atas kelebihan barang yang dijual tanpa dilebih-lebihkan.

Diantara tindakan fraud dalam Islam adalah pasar manipulasi (najash). Ibnu 'Umar menjelaskan bahwa najash menandakan penawaran seseorang untuk barang tertentu tanpa ada niat untuk benar-benar membeli, tetapi hanya untuk mendorong agar orang lain menawar lebih tinggi. Selain melarang manipulasi pasar, dalam hadits riwayat Muslim, Nabi Muhammad juga melarang transaksi jual beli atas barang yang masih dalam perjalanan ke pasar. Sebaliknya, memberitahu mereka untuk menunggu hingga barang sampai di pasar. Larangan ini relevan untuk memastikan bahwa penjual tidak tertipu atas kurangnya pengetahuan tentang harga barang dagangannya.

Dalam Ibrahim, at al. (2013), terdapat beberapa jenis penipuan (fraud) yang berhubungan dengan malpraktik kelembagaan seperti ketidak jujuran, kebohongan dan pelanggaran pakta atau janji, ketidak setiaan (khiyanah), dan suap (risywah). Selain itu, tindakan lain seperti penjualan secara gharar (ketidak pastian) dan ihtikar (penimbunan) juga dianggap dengan penipuan.

Secara harfiah, ketidakjujuran berarti kurangnya kejujuran atau integritas yang 
selanjutnya menjadi disposisi untuk melakukan penipuan. Sebuah tindakan ketidak jujuran setara dengan penipuan. Ketidakjujuran merupakan salah satu bentuk terburuk dari sebuah penipuan, seseorang yang tidak jujur selalu rentan untuk menipu orang lain kapanpun dan dimanapun. Diantara tindakan tidak jujur ialah kegiatan penggelapan, penyalahgunaan, pengrusakan, penghapusan, penyembunyian, perubahan, serta pemalsuan, termasuk penghancuran atas dokumen, klaim palsu, pencurian asset, serta tindakan suap.

\section{METODE PENELITIAN}

\section{Jenis Penelitian dan Gambaran Informan Penelitian}

Penelitian ini termasuk dalam jenis penelitian kualitatif berbasis studi kasus, yang dilakukan pada salah satu Bank Syariah $X$ di Propinsi Jawa Timur dengan durasi waktu selama 6 bulan. Kriteria informan yang dipilih diharapkan dapat membantu mengungkap fenomena fraud pada bank syariah antara lain: informan yang pernah melakukan fraud ataupun pernah menjadi atasan langsung pelaku fraud yang terdiri dari, pertama, pelaku fraud, kedua, atasan langsung pelaku fraud, ketiga, rekan seprofesi pelaku fraud dan keempat, auditor internal cabang.

\section{Teknik Pengumpulan Data}

Menurut Rahardjo (2017), teknik pengumpulan data dalam penelitian studi kasus dapat diperoleh melalui beberapa teknik yaitu studi kepustakaan, wawancara, dan dokumentasi. Adapun penjelasan dari masing-masing teknik pengumpulan data pada penelitian ini adalah sebagai berikut. Pertama, Studi Kepustakaan, metode ini dilakukan untuk mendapatkan sumbersumber informasi teoritis terkait masalah yang diangkat pada penelitian ini. Sumbersumber informasi yang digunakan pada studi kepustakaan ini adalah seperti buku, artikel jurnal, media elektronik, Al-Qur'an dan Al-Hadits.
Hasil informasi yang diperoleh dari studi kepustakaan ini selanjutnya digunakan sebagai sumber acuan untuk menelaah hasil penelitian yang telah diperoleh. Kedua, Metode Wawancara, metode ini adalah bertujuan untuk mendapatkan informasi primer terkait kronologi tindakan fraud yang terjadi serta informasi primer lainnya yang berhubungan. Metode wawancara pada penelitian ini dilakukan dengan menggunakan wawancara terstruktur.

Tujuannya agar pertanyaan yang diajukan pada saat wawancara tidak keluar dari tujuan penelitian yang telah ditentukan sebelumnya. Metode wawancara ini dilakukan kepada pihak-pihak yang terkait dengan tindakan fraud yang terjadi. Ketiga, Metode Dokumentasi, metode yang dilakukan dengan tujuan untuk mengumpulkan dokumen-dokumen terkait dengan tindakan fraud yang telah dilakukan. Metode ini dilakukan untuk memberikan bukti pendukung untuk memperkuat hasil penelitian yang telah dilakukan pada metode-metode sebelumnya. Dengan demikian, hasil penelitian yang diperoleh akan lebih valid.

\section{Analisis Data}

Analisis data yang digunakan pada penelitian ini adalah dengan menggunakan metode triangulasi. Metode triangulasi dalam penelitian kualitatif terdiri dari empat macam yaitu trianguluasi sumber, triangulasi peneliti, triangulasi metodologis, dan triangulasi teoritis (Hadi, 2016). Selain menggunakan metode triangulasi, penulis dalam penelitian ini juga menggunakan analisis kasyf.

Analisis kasyf digunakan untuk menganalisa bagaimana ajaran yang terkandung dalam al-Qur'an dan al-Hadits yang diimplementasikan dalam mendeteksi perilaku fraud pada bank syariah. Analisis kasyf bukan untuk menguji kebenaran al-Qur'an dan al-Hadits sebagai teori namun ajaran yang ada dalam al-Qur'an dan al-Hadits dapat menjadi sumber ilmu pengetahuan. Analisis kasyf ditujukan untuk mengkaji alQur'an dan as-Sunnah untuk memperoleh 
sumber pengetahuan yang relevan dengan variabel-variabel yang diteliti.

\section{ANALISIS DAN PEMBAHASAN Gambaran Umum Informan}

Penelitian ini dilakukan pada Bank Syariah X (selanjutnya disingkat BSX) di Jawa Timur dengan informan yang merupakan pegawai internal perusahaan. Hasil penelitian ini diperoleh dari wawancara kepada para pelaku fraud, rekan seprofesi pelaku, serta auditor internal. Pelaku fraud dalam penelitian ini merupakan pegawai pelaksana yang menjabat sebagai frontliner, serta atasan langsung pelaku yang merupakan seorang manajer. Berikut profil informan yang diringkas dalam tabel berikut.

Tabel 1

\section{Profil Informan}

\begin{tabular}{ccll}
\hline No. & Nama Inisial & Jabatan & \\
\hline 1. & $\mathrm{~T}$ & Frontliner & \\
2. & $\mathrm{~B}$ & Manajer & \\
3. & $\mathrm{I}$ & $\begin{array}{l}\text { Teman Sejawat } \\
\text { dan B }\end{array}$ & $\mathrm{T}$ \\
4. & A & Auditor Internal & \\
\hline
\end{tabular}

Sumber: data penelitian diolah (2019)

BSX diketuai oleh kepala cabang yang ditunjuk oleh direksi. Dalam mencapai tujuan kantor cabang, kepala cabang dibantu oleh manajer operasional dan manajer marketing. Manajer operasional bertanggung jawab atas kelancaran operasional harian kantor dan menjadi atasan langsung dari para pegawai pelaksana harian yang terdiri dari frontliner, back office, bagian umum, HRD, dan pegawai lain yang bertanggung jawab menjaga kelancaran operasional perbankan. Sedangkan manajer marketing bertanggung jawab atas tercapainya target kantor, baik target pendanaan maupun pembiayaan.

\section{Karakter dan Kepribadian Pelaku Fraud T}

Pelaku fraud dalam sebuah organisasi atau perusahaan, dapat dikelompokkan menjadi employee fraud dan management fraud. Employee fraud merupakan fraud yang dilakukan oleh pegawai, baik sendiri maupun bekerjasama dengan beberapa pegawai terkait. Sedangkan management fraud merupakan fraud yang dilakukan oleh pihak manajemen. Umumnya, management fraud menggunakan laporan keuangan perusahaan sebagai sarana untuk melakukan fraud. Pelaku fraud pada penelitian ini tergolong dalam employee fraud. Hal ini dikarenakan peristiwa fraud yang dilakukan oleh pelaku tidak menggunakan laporan keuangan. Namun, perbuatan fraud yang dilakukan oleh pelaku sebagai pegawai BSX adalah murni dengan memanfaatkan posisi pelaku dalam perusahaan. Pelaku merupakan seorang frontliner BSX berinisial T yang telah bekerja pada BSX sejak tahun 2009. Sebagai seorang frontliner yang termasuk dalam pegawai pelaksana, sangat tidak mungkin jika $\mathrm{T}$ melakukan perbuatan fraud seorang diri. Pada BSX, seorang frontliner memiliki pagu transaksi maksimal yang dapat ditransaksikan tanpa otorisasi dari atasan langsung.

Nilai pagu maksimal, berbeda antara satu frontliner dengan frontliner yang lain. Hal ini bergantung pada unit tempat bertugas serta lama masa jabatan pegawai. Seorang frontliner baru memiliki pagu maksimal yang dapat ditransaksikan tanpa otorisasi dari atasan langsung adalah 5 juta rupiah. Sedangkan, untuk frontliner yang telah menduduki jabatan tersebut lebih dari satu tahun memiliki pagu maksimal sebesar 25 juta rupiah. Artinya, pelaku untuk melakukan fraud dengan nominal diatas pagu maksimal yang dimiliki, pelaku $\mathrm{T}$ harus bekerja sama dengan atasan langsungnya. Hal ini dikarenakan pelaku tidak mungkin dapat melakukan fraud tanpa adanya kerjasama dengan atasan langsung.

Tidaklah sulit bagi $\mathrm{T}$ untuk mendapatkan restu dari B selaku atasan langsungnya. Pada dasarnya, $\mathrm{T}$ dan $\mathrm{B}$ sudah sangat akrab karena gaya hidup mereka yang sama. Diluar pekerjaannya sebagai pegawai bank, 
$\mathrm{T}$ juga merupakan talent yang aktif mengikuti perhelatan fashion tingkat internasional yang diselenggarakan setiap tahun di kabupaten di Jawa Timur. Gaya hidup dari para talent di ajang tersebut sudah tidak diragukan lagi. Maka tidak heran, jika $\mathrm{T}$ selalu berusaha terlihat mewah dan glamour di depan rekan kerjanya. Hal ini terlihat dari kendaraan serta atribut yang dipakainya untuk bekerja, seperti tas serta jam tangan. Bahkan tidak jarang, T menceritakan harga barang yang dipakainya, yang terbilang cukup mahal untuk seorang frontliner. Atas kemampuan untuk membeli barang dengan harga yang tidak murah tersebut, sangat wajar jika kemudian menimbulkan pertanyaan tentang darimana asal dana yang digunakannya untuk memenuhi tuntutan perkembangan gaya hidupnya.

\section{Karakter dan Kepribadian Pelaku Fraud B}

Dalam dunia perbankan, pegawai pelaksana memiliki seseorang atasan yang berada pada jajaran manajer. Atasan langsung $\mathrm{T}$, berinisial $\mathrm{B}$, merupakan seorang manajer. Sebelum menjadi manajer, $B$ merupakan seorang back office yang bertugas pada cabang lain. Karena dianggap mampu, B kemudian mendapatkan amanah dari direktur utama untuk menjadi seorang manajer pada kantor cabang di Jawa Timur. Sesuai peraturan BSX, pegawai yang menjabat sebagai manajer dan kepala cabang tidak dapat bertugas pada unit yang merupakan home base pegawai. Dalam hal ini, home base merupakan unit atau cabang awal dimana pegawai tersebut diterima sebagai pegawai perusahaan. Sehingga, B yang awalnya merupakan pegawai pada salah satu cabang di Jawa Tengah, selanjutnya mendapatkan amanah untuk menjadi seorang manajer pada cabang di Jawa Timur. Salah satu tugas B, sebagai seorang manajer adalah melakukan otorisasi atas transaksi yang melebihi limit atau pagu transaksi frontliner. Dalam melakukan otorisasi, B harus meneliti form transaksi nasabah, untuk kemudian dicocokkan dengan jumlah uang serta apa yang diinput oleh frontliner. Apabila telah sesuai, maka B sebagai manajer dapat melakukan otorisasi transaksi. Khusus untuk transaksi yang tidak melibatkan uang, seperti pembukaan rekening baru dan transfer antar rekening, frontliner harus meminta otorisasi manajer, berapapun jumlah transaksinya.

Dalam gambar selanjutnya, penulis menggambarkan secara ringkas prosedur kerja pelaku sebagai seorang frontliner serta manajer dalam transaksi penarikan. Pada gambar tersebut dapat diketahui bahwa transaksi penarikan dimulai dengan penyerahan form penarikan oleh nasabah. Nasabah yang akan melakukan penarikan saldo harus mengisi form penarikan, kemudian menyerahkan kepada frontliner disertai buku tabungan serta KTP asli. Selanjutnya frontliner memeriksa form penarikan, termasuk mencocokkan nama dan tanda tangan penarik dengan nama dan tanda tangan yang telah tertera pada buku tabungan serta KTP. Apabila tidak sesuai, frontliner wajib menolak transaksi tersebut dengan mengembalikan form, buku tabungan, serta KTP kepada penarik. Namun apabila telah sesuai, frontliner akan melakukan penginputan transaksi penarikan tersebut pada sistem perusahaan sesuai dengan form penarikan yang telah diisi nasabah.

Setelah proses input data penarikan selesai dilakukan, validasi transaksi dapat dicetak pada form penarikan, dan sistem secara otomatis akan meminta otorisasi kepada manajer manakala penarikan yang dilakukan oleh nasabah melebihi jumlah pagu maksimal frontliner. Selanjutnya, manajer akan memeriksa kesesuaian form penarikan, validasi transaksi, data nasabah, serta jumlah uang tunai yang akan diserahkan kepada nasabah, sebelum manajer melakukan otorisasi pada sistem perusahaan. Validasi pada buku tabungan nasabah baru dapat dicetak setelah manajer melakukan otorisasi pada sistem.

\section{Tanda-tanda Terjadinya Fraud}

Fraud merupakan sebuah kejahatan yang dilakukan secara sembunyi-sembunyi 
(Yurmaini, 2017). Sebagian besar manajemen perusahaan mengklasifikasikan fraud kedalam kejahatan luar biasa dan menganggap bahwa fraud merupakan penyakit yang dapat menular, sehingga mereka tidak segan untuk memberikan sanksi berupa pemutusan hubungan kerja (PHK) bagi pelaku fraud. Pelaku fraud umumnya menyadari bahwa punishment bagi pelaku fraud dapat membuatnya kehilangan pekerjaan. Beratnya sanksi dari perusahaan membuat pelaku fraud akan selalu berusaha untuk menutupi kesalahannya dengan cara apapun. Hal ini untuk menghindari resiko punishment yang akan didapatkan saat kejahatan tersebut terungkap. Menurut auditor internal kantor pusat BSX, tanda-tanda awal pegawai yang berpotensi melakukan fraud dapat terlihat dari tingkah laku sebagai berikut:

1. Jarang mengajukan cuti, ataupun ijin sakit,

2. Datang paling awal dan pulang akhir,

3. Mengerjakan semua pekerjaan sendiri,

4. Melakukan transaksi fraud saat kondisi nasabah ramai, atau menjelang jam tutup kas,

5. Permintaan otorisasi transaksi dengan terburu-buru,

6. Gaya hidup yang melebihi gaji yang didapat.

Fraud yang dilakukan oleh $\mathrm{T}$ dan $\mathrm{B}$ awalnya terungkap dari laporan dua rekan kerja $\mathrm{T}$ sesama frontliner yang mencurigai transaksi yang diperintahkan oleh B. Transaksi tersebut merupakan transaksi penarikan dari rekening nasabah prioritas yang selanjutnya disetorkan ke rekening $\mathrm{B}$. Nasabah prioritas yang menjadi korban, diketahui masih ada hubungan keluarga dengan T. Rekan kerja T yang mendapatkan perintah untuk melakukan transaksi penarikan, menanyakan kepada B keberadaan nasabah prioritas untuk mengkonfirmasi transaksi tersebut, namun B melarangnya dengan alasan $\mathrm{B}$ telah mengkonfirmasi kepada nasabah yang bersangkutan dan meminta uang tunai hasil penarikan dititipkan kepada B. Beberapa jam kemudian, $B$ menyetorkan uang tunai tersebut kepada rekening $\mathrm{B}$.

Atas transaksi tersebut, kedua frontliner yang mendapat perintah untuk menjalankan transaksi merasa curiga. Untuk melindungi diri dari transaksi tidak wajar yang selanjutnya dapat menjadi temuan audit kantor pusat, kedua frontliner melaporkan kepada auditor internal cabang. Selanjutnya, laporan tersebut ditindak lanjuti oleh auditor internal cabang.

Hasil penyelidikan auditor internal cabang menjadi laporan kepada auditor internal pusat.

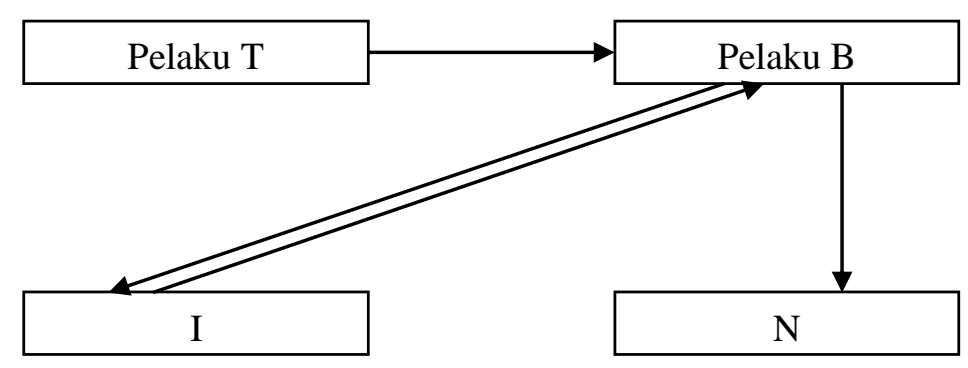

Gambar 1

Alur Kasus Fraud

Sumber: data penelitian diolah (2019)

\section{Keterangan:}

1. $\mathrm{T}$ memberikan form penarikan atas rekening salah satu nasabah prioritas yang telah dibubuhkan tanda tangan palsu kepada B.

2. B memberikan form penarikan yang diberikan T kepada I. Dengan alasan 
nasabah yang bersangkutan menitipkan sendiri form penarikan tersebut kepada B, B melarang I untuk melakukan konfirmasi penarikan kepada pemilik rekening tersebut.

3. Setelah melakukan transaksi penarikan, I menyerahkan uang tunai kepada B dengan jumlah nominal sesuai dengan yang tertera pada form penarikan.

4. Beberapa jam kemudian, B menyerahkan uang tunai dari transaksi penarikan tersebut kepada $\mathrm{N}$ untuk disetorkan kepada rekening pribadi $\mathrm{B}$.

\section{Ilustrasi Kejadian Menurut Pelaku T}

Fraud dapat terjadi karena disebabkan oleh empat sebab menurut The New Fraud Triangle Model. Kassem dan Hingson (2012) menyatakan bahwa fraud dapat terjadi karena adanya motivasi, kesempatan, integritas, serta kemampuan dari para pelaku. Motivasi umumnya tercipta karena adanya keinginan untuk selalu mengikuti gaya hidup orang lain, tanpa memperhitungkan pendapatan yang diterima setiap bulannya. Kesempatan muncul saat pelaku sudah mengetahui seluk beluk pekerjaan dengan baik. Pegawai yang menduduki suatu jabatan dengan masa waktu yang terlalu lama, akan mengetahui titik kelemahan fungsi kontrol suatu sistem dengan mudah. Selanjutnya, dengan kesempatan dan integritasnya sebagai pegawai, akan memunculkan kemampuan dari pelaku untuk melakukan fraud.

Berikut penulis lampirkan petikan hasil wawancara penulis dengan $\mathrm{T}$ yang merupakan pelaku fraud antara lain:

1. Q : Dimana anda melakukan fraud?

A : Sejak awal menjadi pegawai BSX, saya ditempatkan di kantor cabang di Jawa Timur. Sehingga saya melakukan fraud di BSX.

2. Q : Apa posisi anda di BSX?

A : Saya merupakan salah satu frontliner senior disana. Senior bukan karena penilaian atasan. Namun masa jabatan yang lama bagi saya dalam menjabat sebagai seorang frontliner menjadikan saya seorang senior. Frontliner yang seangkatan dengan saya telah berpindah jabatan. Masa jabatan yang lama menjadikan saya sangat dekat dengan pak B, sebagai atasan langsung saya. Selain masa jabatan yang lama, saya juga menyadari bahwa kami memiliki gaya hidup yang sama. Atas kedekatan ini, pak B menjadikan saya sebagai orang kepercayaannya. Hal ini dapat kamu lihat sendiri, bagaimana pak B mempercayakan user serta password otorisasinya hanya kepada saya.

3. Q : Sejak kapan anda menyadari adanya kesamaan gaya hidup antara anda dengan pak B?

A : Pak B ditempatkan sebagai manajer BSX sejak akhir tahun 2010. Kira-kira dua tahun sejak aku resmi menjadi pegawai BSX. Sejak awal kedatangan beliau, saya sudah melakukan pendekatan. Biasalah, tujuan saya hanya agar karir saya disini mulus. Karena beliau bukan penduduk asli kota ini, saya menunjukkan kepada beliau apa saja yang terdapat di sini. Termasuk tempat wisata, dan sekolah bagi anaknya. Bahkan lokasi rumah yang tepat bagi beliau, juga atas saran saya. Sejak saat itu, saya menyadari bahwa gaya hidup kami sama. Namun penghasilan kami sebagai seorang pekerja membuat kami tidak dapat mengikuti perkembangan gaya hidup yang berkembang dengan sangat cepat. Bahkan kami juga sepakat, bahwa penghasilan yang kami terima juga tidak sepadan dengan apa yang telah kami korbankan bagi perusahaan.

4. Q : Bagaimana anda melakukan fraud?

A : Salah seorang kerabat istri saya menjadi nasabah priority. Atas banyaknya rekening beliau yang tersebar di beberapa bank, seringkali beliau nggak peduli dengan jumlah tabungannya yang terdapat di BSX. Hal itu menjadi celah bagiku untuk melakukan fraud. Apalagi tanda tangan beliau juga mudah untuk ditiru. Selain itu, sebagai frontliner saya memiliki cadangan copy KTP beberapa 
nasabah priority. Hal ini untuk mempermudah pekerjaan agar dapat memberikan layanan prima bagi nasabah, sehingga pada saat nasabah priority bertransaksi, kami tidak perlu meminta copy KTP mereka untuk konfirmasi. Dari situ, saya dapat dengan mudah memalsukan tanda tangan beliau pada form penarikan. Selanjutnya, form penarikan yang telah saya bubuhkan tanda tangan palsu tersebut saya serahkan kepada bapak B beserta copy KTP nasabah. Dengan alasan nasabah priority, bapak B dengan mudah memerintahkan rekan frontliner saya untuk mengeksekusi transaksi penarikan tersebut pada pagi hari, saat jam kas baru dimulai. Saat uang tunai telah diterima oleh bapak B, setelah jam istirahat bapak B memerintahkan rekan frontliner yang lain untuk melakukan penyetoran uang tunai kepada rekening pribadinya.

5. Q : Berapa nilai transaksi tersebut? A : Hanya Rp 150 juta.

6. Q : Apakah nilai tersebut merupakan total fraud yang anda lakukan?

A : Tidak. Itu hanya satu transaksi saja. Saya tidak ingat betul berapa kali saya melakukannya. Termasuk juga jumlahnya, saya tidak mengingatnya.

Dari petikan wawancara penulis dengan pelaku T, dapat penulis jelaskan bahwa pelaku merupakan seorang frontliner yang telah menjabat selama lebih dari 5 tahun. Artinya, pelaku telah benar-benar memahami seluk-beluk, kelemahan, serta kekurangan dari sistem perusahaan yang berkaitan dengan frontliner. Dalam dunia perbankan, dikenal istilah nasabah umum dan nasabah prioritas. Nasabah prioritas merupakan nasabah yang memiliki tidak hanya satu produk perbankan, dengan total simpanan yang juga tidak sedikit. Nasabah prioritas tidak hanya merupakan nasabah perorangan, namun juga nasabah korporasi. Atas kontribusi nasabah prioritas kepada perusahaan, maka pelayanan yang diberikan untuk nasabah prioritas juga sangat isti- mewa. Contohnya, nasabah prioritas memiliki berhak untuk mendapatkan layanan pick up service, yaitu layanan jemput dana nasabah yang akan disetorkan kepada rekeningnya, tanpa harus datang ke bank. Nantinya, petugas dari bank yang akan mendatangi rumah ataupun kantor nasabah untuk mengambil dana yang akan disetorkan. Dana yang akan disetorkan, dihitung oleh petugas bank yang datang kepada nasabah, di hadapan nasabah. Selanjutnya, nasabah diberikan tanda terima non validasi atas setoran tersebut, yang berisi nama dan nomor rekening nasabah, jumlah setoran nasabah berupa angka beserta terbilangnya, tanggal transaksi, serta tanda tangan pegawai yang bersangkutan. Setelah kembali ke bank, pegawai yang bertugas melakukan pick up service, melakukan penyetoran dana nasabah kepada teller. Teller memberikan tanda terima kepada petugas pick up service, dengan validasi tercetak, setelah teller melakukan input data transaksi sesuai standar operasional dan penerapan standar operasional prosedur (SOP) teller.

Untuk penarikan dana, nasabah prioritas tidak dapat menggunakan fasilitas pick up service. Dalam SOP, untuk transaksi penarikan rekening nasabah tetap harus datang sendiri ke bank untuk melakukan penarikan dana tanpa harus mengantri sebagaimana layaknya nasabah umum. Beberapa perusahaan perbankan memiliki ruang khusus untuk melayani transaksi perbankan nasabah prioritas, termasuk untuk layanan setoran dan penarikan tunai. Hal ini untuk menghindari adanya celah untuk melakukan fraud atas transaksi penarikan dana nasabah prioritas. Dapat dibayangkan, saat nasabah akan melakukan penarikan dana, namun nasabah menginginkan layanan tanpa harus datang ke bank, maka nasabah harus menyerahkan form penarikan tunai kepada petugas pick up service. Selanjutnya, petugas pick up service melakukan penarikan dana nasabah kepada teller, dan teller menyerahkan dana sebesar transaksi nasabah yang terdapat pada form 
penarikan tunai kepada petugas pick up service. Hal ini tentu dapat menjadi celah untuk terjadinya kecurangan, seperti dana yang diserahkan kepada nasabah ternyata lebih kecil daripada nominal yang terdapat pada form penarikan yang telah ditandatangani sebelumnya oleh nasabah.

Oleh sebab itu, auditor internal mewajibkan transaksi penarikan tunai nasabah prioritas, untuk tetap dilakukan di bank. Sebagai gantinya, nasabah prioritas berhak untuk menerima fasilitas pengawalan oleh security bank, untuk menghindari hal-hal yang tidak diinginkan terjadi di jalan, seperti pembegalan maupun perampokan.

Berdasarkan hak istimewa yang didapatkan oleh nasabah prioritas, serta pengalaman pegawai yang telah menempati suatu posisi dalam jangka waktu yang lama, dapat menjadikan seorang pegawai untuk benar-benar memahami seluk beluk kelebihan serta kelemahan sistem perbankan untuk melakukan fraud. Sebagaimana yang dikatakan oleh $\mathrm{T}$ sebagai pelaku fraud, bahwa $\mathrm{T}$ menggunakan fasilitas yang didapatkan oleh nasabah prioritas untuk mendukung aksinya. Seringnya melayani nasabah prioritas yang melakukan transaksi perbankan, ditambah dengan hubungan nasabah yang merupakan saudara dari istri $\mathrm{T}$, membuat $\mathrm{T}$ dapat menghafal dengan benar, tanda tangan nasabah yang menjadi korban T.

Namun untuk melancarkan aksinya, $\mathrm{T}$ juga membutuhkan persetujuan $B$, yang merupakan atasan langsung T. Tidak susah bagi $\mathrm{T}$ untuk mendapatkan persetujuan $\mathrm{B}$ dalam melancarkan aksinya, karena gaya hidup B yang juga serba wah, serta tuntutan menjaga gengsi karena jabatan yang didudukinya sebagai manajer. Bahkan tidak jarang, B melakukan sharing password atas user otorisasinya kepada $\mathrm{T}$ dengan tujuan untuk mempermudah dan mempercepat proses transaksi nasabah saat B sedang tidak ada di tempat untuk keperluan mendesak, seperti saat B sedang ke rest room, meeting dengan jajaran manajemen, serta saat $\mathrm{B}$ sedang sholat. Sehingga, nasabah yang bertransaksi melebihi batas pagu frontliner, tidak perlu menunggu lama untuk mendapatkan otorisasi transaksi dari manajer karena manajer sedang tidak ada di tempat, namun $\mathrm{T}$ dapat langsung melakukan proses otorisasi transaksi nasabah dengan menggunakan user otorisasi B dengan password yang telah diketahuinya.

Meskipun $\mathrm{T}$ telah mengetahui password user otorisasi yang dipegang oleh $\mathrm{B}$, namun dalam kejadian fraud, $\mathrm{T}$ tidak pernah melakukan otorisasi sendiri. $\mathrm{T}$ selalu bekerjasama dengan $\mathrm{B}$ dalam setiap kejadian fraud yang dia lakukan. Artinya, T tidak berani melakukan fraud seorang diri. Dalam melakukan aksinya, $\mathrm{T}$ selalu melibatkan $\mathrm{B}$. Menurut T, hal ini dia lakukan sebagai upaya mengamankan diri. Sehingga, apabila suatu saat aksi $\mathrm{T}$ diketahui oleh auditor, $\mathrm{T}$ bukan merupakan tersangka tunggal. Namun $\mathrm{T}$ akan berusaha meminta perlindungan kepada B sebagai atasan langsungnya. Umumnya, atasan langsung akan melindungi bawahannya dari temuan auditor, sepanjang kesalahan yang diperbuat oleh bawahan, tidak berakibat fatal dan bukan merupakan kesalahan yang disengaja, seperti kurangnya tanda tangan nasabah pada bagian belakang form penarikan.

\section{Ilustrasi Kejadian Menurut Pelaku B}

Cressey (1950), berpendapat bahwa fraud terjadi karena adanya tekanan (pressure) atas kebutuhan pribadi, seperti gaya hidup atau keterlilitan atas hutang, yang kemudian disadari dengan adanya kesempatan (opportunity) untuk melakukan sebuah fraud, dan selanjutnya pelaku mendapatkan alasan rasional (rationalization) untuk membenarkan tindakannya.

Dari hasil wawancara penulis kepada atasan langsung pelaku fraud yang juga terlibat dalam kasus fraud yang dilakukan oleh bawahannya, dapat dikumpulkan beberapa informasi untuk menyusun predikasi $5 \mathrm{~W} 1 \mathrm{H}$. Berikut petikan wawancara penulis dengan pelaku B:

1. Q : Dimana bapak melakukan fraud? 
A : Hanya di BSX. Karena hanya disitu saya punya kesempatan untuk melakukannya.

2. Q : Apa posisi bapak di BSX?

A : Saya ditugaskan di BSX sebagai manajer. Dengan posisi itu, saya memiliki wewenang untuk memberikan otorisasi atas transaksi yang melebihi limit transaksi frontliner.

3. Q : Menurut $T$, sebagai bawahan bapak, bapak dan $\mathrm{T}$ memiliki kesamaan gaya hidup. Sejak kapan bapak menyadari adanya kesamaan gaya hidup tersebut?

A : Saya ditugaskan menjadi manajer pada BSX pada akhir tahun 2010. Sejak awal kedatangan saya di BSX, saya dekat dengan mas T. Saya pikir, karena mas $\mathrm{T}$ sudah lama menduduki posisinya sebagai seorang frontliner, dia pasti sangat paham dengan seluk-beluk operasional di BSX, terutama untuk bagian frontliner. Selain itu, dari pembicaraan ringan kami di selasela tugas kantor, ternyata dia juga pandai dalam memberikan saran yang sesuai dengan keinginan saya. Hal itu terbukti, saya mendapatkan rumah dinas di lokasi yang sesuai dengan kriteria yang saya inginkan. Sebagai seorang manajer, saya harus menjaga image saya dimata masyarakat. Termasuk masalah penampilan dan lokasi tempat tinggal.

4. Q : Sebelum bapak ditempatkan sebagai manajer di BSX, apa jabatan bapak?

A : Sejak awal bekerja di dunia perbankan, saya selalu menempati posisi di bagian operasional. Mulai dari admin pembiayaan, back office, dan bagian sumber daya. Namun saya belum pernah menjadi frontliner. Maka dari itu, saya dekat dengan mas $\mathrm{T}$, agar saya paham seluk beluk pekerjaan frontliner. Karena bagian operasional rentan terhadap fraud, saya pikir saya harus benar-benar paham kelebihan dan kelemahan sistem perusahaan. Namun setelah saya pahami, ternyata justru saya yang tergoda untuk melakukannya.

5. Q : Bagaimana bapak melakukan fraud?
A : Saat itu, saya dan mas T sedang samasama membutuhkan uang dalam jumlah besar. Tapi saya lupa untuk apa. Lalu mas T mengatakan bahwa dia akan mengecek rekening nasabah. Setelah dipastikan dananya besar, saya dan mas $\mathrm{T}$ mempunyai ide untuk memalsukan tanda tangan nasabah tersebut di form penarikan. Kemudian saya akan meminta kedua rekan mas $\mathrm{T}$ sebagai frontliner untuk memproses transaksi penarikan dari rekening nasabah itu, dan untuk memproses transaksi penyetoran ke rekening saya. Saya pikir, saya tidak boleh memerintahkan hanya satu orang frontliner saja untuk memproses kedua transaksi ini. Karena riskan akan munculnya kecurigaan. Meskipun saya membagi kedua transaksi ini untuk diproses oleh dua orang frontliner, tidak menutup kemungkinan mereka tidak curiga. Karena meja keduanya bersebelahan. Jadi saat saya memberikan form penarikan, saya katakan kepada frontliner tersebut bahwa ini adalah pembayaran transaksi jual-beli antara saya dengan nasabah ini.

6. Q : Berapa nilai transaksi tersebut?

A : Seratus lima puluh juta.

7. Q: Apakah nilai tersebut merupakan total transaksi yang pernah bapak lakukan?

A : Tidak. Saya tidak ingat betul berapa totalnya. Dan saya yakin mas T juga tidak ingat.

Dari petikan wawancara penulis dengan pelaku B, dapat penulis simpulkan bahwa pelaku merupakan karyawan yang baru ditugaskan pada BSX sebagai manajer. Sejak awal kedatangannya, pelaku B telah menyadari adanya kesamaan gaya hidup dengan pelaku $\mathrm{T}$, dan berpendapat bahwa gaji yang mereka dapatkan tidak sesuai dengan beban kerja mereka. Menurut B sebagai manajer, "kita mengorbankan waktu, tenaga dan pikiran kita dari pagi hingga malam, bekerja 5 hari seminggu, bahkan terkadang harus tetap bekerja di akhir pekan. Namun gaji yang kita dapatkan, 
tidak dapat memenuhi seluruh kebutuhan hidup kita.

Lalu, apakah salah jika kita menginginkan sesuatu yang lebih dari apa yang kita dapatkan? Toh kami juga melebihkan pengorbanan kita demi perusahaan."

\section{Ilustrasi Kejadian Menurut Rekan Seprofesi (I)}

Berikut penulis lampirkan petikan hasil wawancara penulis dengan I yang merupakan rekan seprofesi pelaku fraud:

1. Q : Apa posisi anda di BSX?

A : Sama seperti mas $T$, saya hanya seorang frontliner. Awal menjadi frontliner, mas $\mathrm{T}$ yang mengajari saya.

2. Q : Di unit mana anda bertugas?

A : Pindah-pindah sih. Di payment point pernah, di kantor kas pernah, terakhir di kantor cabang.

3. Q: Kapan anda menyadari mas T dan pak B melakukan fraud?

A : Aku lupa tanggal pastinya.

4. Q : Bagaimana anda mengetahui kejadian fraud tersebut?

A : Yang aku ingat waktu itu masih pagi banget. Jam layanan baru buka, tapi belum ada nasabah yang mau transaksi. Aku dipanggil pak $B$, beliau kasih form penarikan rekeningnya nasabah priority. Beliau bilang tadi sudah konfirmasi ke nasabahnya, jadi aku nggak perlu konfirmasi ulang. Aku percaya aja, soalnya form itu sudah lengkap sama buku tabungan plus copy KTP. Jadi aku transaksikan langsung tanpa konfirmasi ulang. Setelah diotorisasi sama pak B, aku cetak buku tabungan, terus aku kasih bukti validasi, buku tabungan, sama uangnya ke pak B. Siangnya pak B panggil mbak N. Pak B kasih form setoran tunai sama uang tunai ke mbak N. Aku nggak sengaja tanya ke pak B, bukannya itu uang tunai yang tadi ditarik nasabah priority? Soalnya aku liat uang itu sudah ada ban uangnya. Ban uang itu ada parafku, artinya kan aku yang ngeban uang itu. Terus kata pak B, memang iya. Katanya itu uang hasil transaksi jual beli mobil sama nasabah priority itu. Tapi aku sama mbak $\mathrm{N}$ agak nggak percaya sih. Pak B kan nggak punya mobil sendiri. Beliau kan biasa pake mobil kantor kalo berangkat sama pulang kerja. Dari situ, aku sama mbak $\mathrm{N}$ inisiatif lapor ke auditor internal. Takut ada apa-apa dikemudian hari. Biar aku sama mbak $\mathrm{N}$ nggak dituduh bekerjasama dalam fraud, jadi kami laporkan saja. Masalah itu transaksi bener atau fraud, biar auditor yang cari tau.

5. $\mathrm{Q}$ : Berapa nilai transaksi tersebut?

A : Seingetku Rp 150 juta.

Dari petikan wawancara penulis dengan rekan seprofesi pelaku, dapat penulis simpulkan bahwa kejadian fraud yang dilakukan oleh $\mathrm{T}$ dan $\mathrm{B}$ sesuai dengan keterangan yang penulis dapatkan sebelumnya dari pelaku. Kejadian bermula saat pagi hari $\mathrm{B}$ memerintahkan kepada I untuk melakukan transaksi penarikan atas rekening nasabah priority.

Selang beberapa jam kemudian, B memerintahkan bawahannya yang lain untuk menyetorkan uang yang sebelumnya telah ditarik dari rekening nasabah priority ke rekening pribadi B. Dalam kejadian ini, I maupun $\mathrm{N}$ tidak berani menolak transaksi yang menurut mereka mencurigakan. Hal ini dikarenakan mereka masih merupakan bawahan dari B.

Sudah menjadi rahasia umum, bahwa dalam sebuah perusahaan, bawahan akan melaksanakan apa yang diperintahkan oleh atasannya. Namun I dan $\mathrm{N}$ tidak diam saja dalam menghadapi transaksi yang mereka anggap mencurigakan. Hal ini terlihat dari sikap mereka yang langsung melaporkan transaksi yang mereka anggap mencurigakan tersebut kepada auditor internal cabang.

\section{Ilustrasi Kejadian Menurut Auditor Internal (A)}

Dari hasil wawancara penulis kepada auditor internal cabang yang menangani fraud yang terjadi, dapat dikumpulkan beberapa informasi untuk menyusun 
predikasi 5W1H. Berikut petikan wawancara penulis dengan auditor internal:

1. Q : Dimana pelaku melakukan fraud? A : Pelaku melakukannya di Kantor.

2. Q : Apa posisi pelaku di Kantor?

A : Seorang pelaku merupakan salah satu staf pelaksana yang bertugas sebagai frontliner. Pelaku lainnya merupakan seorang manajer yang tidak lain adalah atasan langsung $\mathrm{T}$.

3. Q : Kapan dan bagaimana kejadian fraud tersebut anda ketahui?

A : Saya tidak dapat memberitahukan waktu pastinya, karena itu rahasia perusahaan. Saat itu saya sebagai auditor internal cabang mendapat laporan atas transaksi mencurigakan yang melibatkan salah seorang manajer. I dan $\mathrm{N}$ yang melaporkannya sendiri. Selanjutnya, saya selidiki kebenaran transaksi tersebut. Hasilnya saya kirimkan ke auditor pusat sebagai laporan pekerjaan saya. Dalam proses selanjutnya, saya sebagai auditor cabang harus bekerjasama dengan auditor pusat untuk menuntaskan kasus ini. Sebenarnya telah lama saya mencurigai gerak-gerik keduanya. Menurut saya, gaya hidup mereka melebihi kewajaran dari gaji yang mereka dapat, seringnya mereka tiba di kantor lebih awal dan pulang paling akhir, serta mereka sangat jarang mengambil hak cuti karyawan. Bahkan saat mereka sakit sekalipun, mereka lebih memilih ijin masuk setengah hari. Seperti ada sesuatu yang mereka sembunyikan, namun saya belum berhasil menemukannya, hingga I dan $\mathrm{N}$ melaporkan transaksi mencurigakan itu.

4. Q : Selanjutnya, bagaimana dengan hasil audit atas transaksi mencurigakan tersebut dan bagaimana penyelesaiannya?

A : Dari laporan tersebut, saya bersama auditor pusat menemukan bahwa ternyata $\mathrm{T}$ menyimpan banyak sekali copy KTP nasabah priority. Namun kami tidak menemukan pelaku melakukan hal yang sama terhadap nasabah priority lain. Artinya, pelaku hanya melakukan ke- curangan terhadap satu nasabah priority saja.

Selanjutnya, temuan ini kami sampaikan kepada jajaran direksi untuk ditindak lanjuti. Bagi kami, sekecil apapun itu, fraud tetaplah penyakit, yang apabila tidak segera disembuhkan, dapat menular ke pegawai lainnya. Atas dasar nilai fraud yang dinilai tidak terlalu material, direksi memutuskan untuk memberhentikan kedua pelaku tanpa memberikan pesangon.

\section{Penanganan Kasus Fraud}

Guna mencegah terjadinya kasus fraud, BSX menerapkan strategi anti fraud yang mengacu pada Surat Edaran Bank Indonesia (SEBI) No. 13/28/DPNP tentang penerapan strategi anti fraud bagi bank umum. Strategi anti fraud diimplementasikan untuk mendukung sistem pengendalian internal perusahaan. Dalam penelitian ini, terungkapnya kasus fraud bermula dari laporan kedua frontliner atas transaksi mencurigakan yang berasal dari perintah manajer. Untuk menghindari temuan auditor pusat, keduanya sepakat untuk melaporkannya terlebih dahulu kepada auditor cabang. Berdasarkan laporan tersebut auditor cabang melakukan investigasi atas transaksi mencurigakan tersebut dan melaporkan hasilnya kepada auditor pusat.

Salah satu implementasi atas pilar kedua dalam hal strategi anti fraud adalah kebijakan dan implementasi atas surprise audit. BSX memberlakukan surprise audit oleh auditor pusat kepada kantor wilayah, kantor cabang, maupun unit-unit dibawahnya, minimal sekali dalam setahun. Namun tidak menutup kemungkinan, surprise audit dilaksanakan lebih dari sekali dalam setahun. Atas laporan auditor cabang, selanjutnya auditor pusat melakukan investigasi pada kantor cabang. Investigasi yang dilakukan auditor kantor pusat, dimulai dari mekanisme surprise audit. Dari surprise audit tersebut, investigasi berkembang kearah yang lebih mendalam terhadap laporan atas 
transaksi mencurigakan. Investigasi tersebut menghasilkan temuan bahwa transaksi tersebut merupakan fraud. Temuan fraud oleh auditor selanjutnya dilaporkan kepada manajemen pusat.

Manajemen pusat memiliki kebijakan zero tolerance bagi segala transaksi yang berkaitan dengan tindakan fraud. Kebijakan zero tolerance dicanangkan karena manajemen pusat mempercayai bahwa fraud merupakan penyakit menular. Sehingga manajemen pusat memberikan sanksi maksimal atas segala sesuatu yang berkaitan dengan fraud. Atas laporan auditor tentang temuan transaksi fraud yang terjadi pada kantor cabang BSX, manajemen pusat melakukan pemanggilan terhadap kedua pelaku, yaitu T dan B. Dengan pertimbangan bahwa nilai fraud tidak terlalu signifikan, manajemen pusat memberikan sanksi pemutusan hubungan kerja (PHK) kepada keduanya.

\section{Pembahasan}

Menurut konsep the new fraud triangle model menjelaskan terjadinya tindakan fraud dari empat perspektif yaitu motivation, capability, opportunity, dan personal integrity. Penjelasan terjadinya tindakan fraud dengan berdasakan pada konsep the new fraud triangle model ini juga dianalisis dengan konsep syariah yang ada pada Al Qur'an dan Hadits. Berikut penjelasan lebih lanjut terkait pembahasan penelitian.

Penghasilan dan Gaya Hidup yang Tidak Seimbang Menjadi Penyebab Kecurangan

Tindakan fraud yang terjadi di BSX dimotivasi oleh adanya ketidakseimbangan antara penghasilan yang diterima oleh pelaku dengan gaya hidup mewah yang dianut oleh pelaku. Hal ini diakui oleh kedua pelaku fraud dari hasil wawancara yang dilakukan dengan pelaku berinisial $\mathrm{T}$ sebagai berikut:

“.....Namun penghasilan kami sebagai seorang pekerja membuat kami tidak dapat mengikuti perkembangan gaya hidup yang berkembang dengan sangat cepat. Bahkan kami juga sepakat, bahwa penghasilan yang kami terima juga tidak sepadan dengan apa yang telah kami korbankan bagi perusahaan."

Perkataan dari pelaku tersebut menunjukkan bahwa kedua pelaku fraud di BSX setuju bahwa penghasilan yang mereka terima dari tempat mereka bekerja saat ini tidak mencukupi untuk memenuhi gaya hidup yang mereka anut. Mereka berpendapat bahwa penghasilan yang mereka terima tidak dapat mengikuti perkembangan gaya hidup yang berkembang sangat cepat dan tidak sesuai dengan apa yang telah diberikan kepada perusahaan.

Ketidakseimbangan antara penghasilan dan gaya hidup yang dianut menjadi motivasi bagi para pelaku untuk melakukan tindakan fraud telah dijelaskan pada konsep the new fraud triangle model. Lister (2007:63) menjelaskan bahwa gaya hidup menjadi salah satu unsur motivasi bagi para pelaku tindakan fraud. Dengan demikian, suatu hal yang umum jika tindakan fraud yang terjadi pada BSX disebabkan oleh adanya gaya hidup yang mewah dari para pelaku (Utari, 2011; Siregar, 2017; Kennedy dan Siregar, 2017).

Adanya ketidakseimbangan antara penghasilan yang diterima oleh para pelaku fraud di BSX menjadi motivasi utama dalam melakukan tindak kecurangan (fraud). Pelaku berinisial $\mathrm{T}$ dan $\mathrm{B}$ sama-sama merasakan ketidakpuasan atas penghasilan (rezeki) yang mereka peroleh. Mereka merasa bahwa rezeki yang telah diberikan Allah S.W.T masih kurang untuk memenuhi kebutuhan hidup mereka. Pada kondisi ini pelaku berinisial $\mathrm{T}$ dan $\mathrm{B}$ sudah terjerumus pada sifat tamak dan rakus yang dapat menjerumuskan mereka kepada perbuatan dosa. Sifat tamak yang muncul pada diri pelaku fraud di BSX pada dasarnya dikarenakan sifat manusia yang tidak pernah merasa puas atas apa yang dimilikinya. Hal ini sesuai dengan penjelasan dari hadits berikut:

"Sungguh, seandainya anak Adam memiliki satu lembah dari emas, niscaya 
ia sangat ingin mempunyai dua lembah (emas). Dan tidak akan ada yang memenuhi mulutnya kecuali tanah.' Kemudian Allâh mengampuni orang yang bertaubat (HR. Al-Bukhâri, no. 6439 dan Muslim, no. 1048)"

Hadits diatas menjelaskan bahwa manusia (anak adam) tidak akan pernah merasa puas meskipun telah diberikan rezeki dalam jumlah yang banyak dan akan selalu terus menginginkan rezeki yang lebih dan lebih lagi. Hadits tersebut juga menjelaskan bahwa ketika orang telah menyadari bahwa di dalam dirinya telah muncul sifat tamak maka segeralah bertaubat agar mendapatkan ampun dari Allah S.W.T.

Sifat tamak akan harta yang dimiliki manusia pada akhirnya akan menyebabkan manusia merugi. Hal ini dikarenakan manusia dengan sifat tamak akan terjerumus pada hal-hal yang penuh dengan dosa dan menghilangkan keberkahan atas harta yang diperolehnya. Nabi Muhammad Shallallahu Aaihi Wasallam pernah mengatakan pada Hakim Bin Hizam:

"Wahai Hakim, sesungguhnya harta itu hijau lagi manis. Barangsiapa yang mencarinya untuk kedermawanan dirinya (tidak tamak dan tidak mengemis), maka harta itu akan memberkahinya. Namun barangsiapa yang mencarinya untuk keserakahan, maka harta itu tidak akan memberkahinya, seperti orang yang makan namun tidak kenyang. Tangan yang di atas lebih baik daripada tangan yang di bawah (HR. Bukhari No. 1472)"

Hadits diatas menunjukkan dengan jelas bahwa manusia tidak dilarang untuk mencari harta selama hidupnya selama dengan niat yang baik dan digunakan untuk kebaikan. Namun, ketika manusia mencari harta dengan diikuti sifat keserakahan maka hal tersebut akan menyebabkan harta yang diperoleh menjadi tidak baik dan berkah bagi dirinya. Oleh karena itu, sifat tamak akan harta harus semaksimal mungkin untuk dapat tinggalkan agar terhindar dari tindakan-tindakan yang berdosa.

\section{Memanfaatkan Posisi Kerja untuk Bertindak Curang}

Kasus fraud yang terjadi pada BSX dapat terjadi karena para pelaku menggunakan posisi pekerjaan yang dimiliki. Posisi pekerjaan yang dimiliki oleh para pelaku ini membuat $\mathrm{T}$ dan $\mathrm{B}$ menjadi lebih leluasa dan memperbesar keinginan mereka untuk melakukan tindakan kecurangan. Hal ini ditunjukkan dengan hasil wawancara berikut:

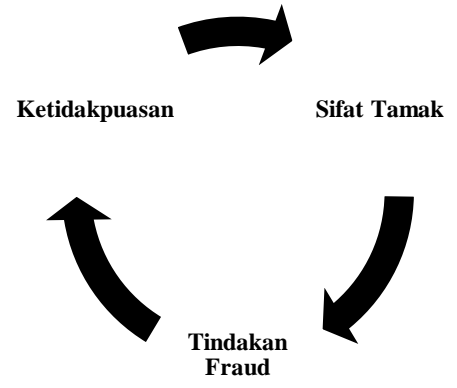

Gambar 2

\section{Hubungan Tamak dan Tindakan Fraud}

Sumber : data penelitian, diolah (2019)

Pelaku T:

"......Selain itu, sebagai frontliner saya memiliki cadangan copy KTP beberapa nasabah priority. Hal ini untuk mempermudah pekerjaan agar dapat memberikan layanan prima bagi nasabah, sehingga pada saat nasabah priority bertransaksi, kami tidak perlu meminta copy KTP mereka untuk konfirmasi....."

Pelaku B:

“.....Lalu mas T mengatakan bahwa dia akan mengecek rekening nasabah. Setelah dipastikan dananya besar, saya dan mas $T$ mempunyai ide untuk memalsukan tanda tangan nasabah tersebut di form penarikan. Kemudian saya akan meminta kedua rekan mas $T$ sebagai frontliner untuk memproses transaksi penarikan dari rekening nasabah itu, dan untuk memproses transaksi penyetoran ke rekening saya. Saya pikir, saya tidak boleh memerintah- 
kan hanya satu orang frontliner saja untuk memproses kedua transaksi ini. Karena riskan akan munculnya kecurigaan. Meskipun saya membagi kedua transaksi ini untuk diproses oleh dua orang frontliner, tidak menutup kemungkinan mereka tidak curiga. Karena meja keduanya bersebelahan. Jadi saat saya memberikan form penarikan, saya katakan kepada frontliner tersebut bahwa ini adalah pembayaran transaksi jual-beli antara saya dengan nasabah ini....."

Berdasarkan kedua hasil wawancara tersebut jelas bahwa pelaku T dan B sama-sama memanfaatkan capability mereka dalam pekerjaan untuk melakukan tindak kecurangan. Pelaku T menggunakan capabilitynya sebagai frontliner yang memiliki data pribadi dari nasabah dalam bentuk copy KTP untuk melancarkan aksinya. Sedangkan, pelaku B menggunakan capability-nya sebagai seorang manajer untuk memerintahkan frontliner lain melakukan transfer ke rekening pribadinya untuk menutupi tindakan kecurangan yang terjadi. Dengan demikian, aksi tindak kecurangan yang dilakukan oleh T dan B dapat berjalan sesuai dengan keinginan mereka.

Capability dari seorang pelaku fraud memang menjadi sebuah pendorong seorang pelaku untuk melakukan fraud yang telah direncanakan. Hal ini telah dijelaskan pada teori the new fraud triangle model yang menjelaskan bahwa fraudster's capability menjadi penyebab terjadinya fraud. Wolfe dan Hermanson (2004) menjelaskan bahwa capability yang dimiliki oleh seorang pelaku fraud dapat menyebabkan munculnya dorongan, memperluas peluang, dan rasionalisasi untuk melakukan fraud. Semakin besar kemampuan (capabilities) yang dimiliki, maka akan semakin besar kemampuan dalam menentukan celah untuk bisa melakukan kecurangan dengan tingkat risiko yang sekecil mungkin agar tidak diketahui oleh pihak lain. Para pelaku fraud pada BSX juga menggunakan posisi pekerjaan yang di- milikinya (capability) untuk melakukan fraud dengan memanfaatkan pegawai yang memiliki posisi dibawah mereka yaitu I. Hal ini diketahui dari hasil wawancara yang telah dilakukan sebagai berikut:

"Sama seperti mas $T$, saya hanya seorang frontliner. Awal menjadi frontliner, mas T yang mengajari saya" "Aku dipanggil pak B, beliau kasih form penarikan rekeningnya nasabah priority. Beliau bilang tadi sudah konfirmasi ke nasabahnya, jadi aku nggak perlu konfirmasi ulang. Aku percaya aja, soalnya form itu sudah lengkap sama buku tabungan plus copy KTP. Jadi aku transaksikan langsung tanpa konfirmasi ulang. Setelah diotorisasi sama pak B, aku cetak buku tabungan, terus aku kasih bukti validasi, buku tabungan, sama uangnya ke pak B."

Penjelasan hasil wawancara diatas menunjukkan bahwa informan I dimanfaatkan oleh pelaku $\mathrm{T}$ dan B untuk melakukan tindakan fraud yang sudah direncanakan. Hasil wawancara secara jelas menunjukkan bahwa informan I merupakan pegawai frontliner yang lebih junior jika dibandingkan dengan pelaku T. Oleh karena itu, pelaku T bisa dengan mudah memanfaatkan I untuk melancarkan aksinya. Selain itu, tindakan fraud $\mathrm{T}$ dan $\mathrm{B}$ lebih mudah berjalan karena informan I sudah percaya dengan form yang diberikan oleh $\mathrm{T}$ kepada dirinya mengingat pelaku T lebih senior dibandingkan dirinya. Penggunaan posisi atau jabatan dari para pelaku untuk melakukan fraud merupakan suatu hal yang jelas tidak sesuai dengan syariah Islam. Hal ini dikarenakan penyalahgunaan posisi atau jabatan itu bertujuan untuk mendapatkan harta demi memenuhi hasrat dan nafsu pribadi pelaku dan telah menyebabkan kerugian kepada pihak lain (nasabah). Islam telah melarang seseorang memperoleh harta melalui cara yang dosa seperti yang dijelaskan pada ayat berikut:

"Dan janganlah sebahagian kamu memakan harta sebahagian yang lain di 
antara kamu dengan jalan yang bathil dan (janganlah) kamu membawa (urusan) harta itu kepada hakim, supaya kamu dapat memakan sebahagian daripada harta benda orang lain itu dengan (jalan berbuat) dosa, padahal kamu mengetahui (Q.S. Al-Baqarah ayat 188)."

Dalam tafsir ibnu katsir surat Al-Baqarah ayat 188 Ali bin Abi Thalhah meriwayatkan, dari Ibnu Abbas, bahwa ayat ini berkenaan dengan seseorang yang mempunyai tanggungan harta kekayaan tetapi tidak ada saksi terhadapnya dalam hal ini, lalu ia mengingkari harta itu dan mempersengketakannya kepada penguasa, sementara dia mengetahui bahwa harta itu bukanlah haknya dan mengetahui bahwa dia berdosa karena memakan barang haram. Dengan demikian, perbuatan yang dilakukan oleh $\mathrm{T}$ dan $B$ secara jelas telah melanggar dan tidak sesuai dengan syariah Islam. Pelaku T dan B telah melakukan perampasan harta milik nasabah yang kemudian digunakan untuk memenuhi kebutuhan pribadi mereka. Tindakan pencurian yang dilakukan oleh $\mathrm{T}$ dan $B$ ini sesungguhnya harus diberikan hukuman yang setimpal. Hal ini sesuai dengan penjelasan yang terdapat pada ayat berikut:

"Laki-laki yang mencuri dan perempuan yang mencuri, potonglah tangan keduanya (sebagai) pembalasan bagi apa yang mereka kerjakan dan sebagai siksaan dari Allah. Dan Allah Maha

Perkasa lagi Maha Bijaksana (Q.S. Al-

Maidah ayat 38)."

Menurut tafsir Ibnu Katsir, melalui ayat diatas Allah memerintahkan untuk memotong tangan pencuri baik laki-laki maupun perempuan. Sebagian fuqaha' berpendapat bahwa jika seseorang mencuri, maka tangannya harus dipotong, berapapun jumlahnya. Hal ini menandakan bahwa pelaku $\mathrm{T}$ dan $\mathrm{B}$ sepatutnya mendapatkan hukuman seperti apa yang telah dijelaskan pada ayat tersebut jika hukuman itu diterapkan. Oleh karena itu, sebisa dan semaksimal mungkin perilaku pencurian harus selalu senantiasa untuk dapat dihindari. Penjelasan pada paragraf sebelumnya secara jelas menjelaskan mengenai adanya fraudster's capability sebagai penyebab terjadinya tindakan kecurangan yang dilakukan oleh pelaku T dan B. Hal ini membuktikan bahwa teori the new fraud triangle model dapat digunakan untuk memprediksi dan menjelaskan fenomena fraud. Selain itu. Penjelasan pada paragraf sebelumnya juga menyiratkan bahwa tindakan kecurangan yang dilakukan oleh $\mathrm{T}$ dan B tidak sesuai dengan apa yang telah diajarkan dalam Islam.

Hal ini dikarenakan tindakan yang dilakukan oleh $\mathrm{T}$ dan $\mathrm{B}$ termasuk perbuatan yang bathil dan dosa. Penjelasan tersebut dapat dijelaskan secara singkat dari gambar berikut:

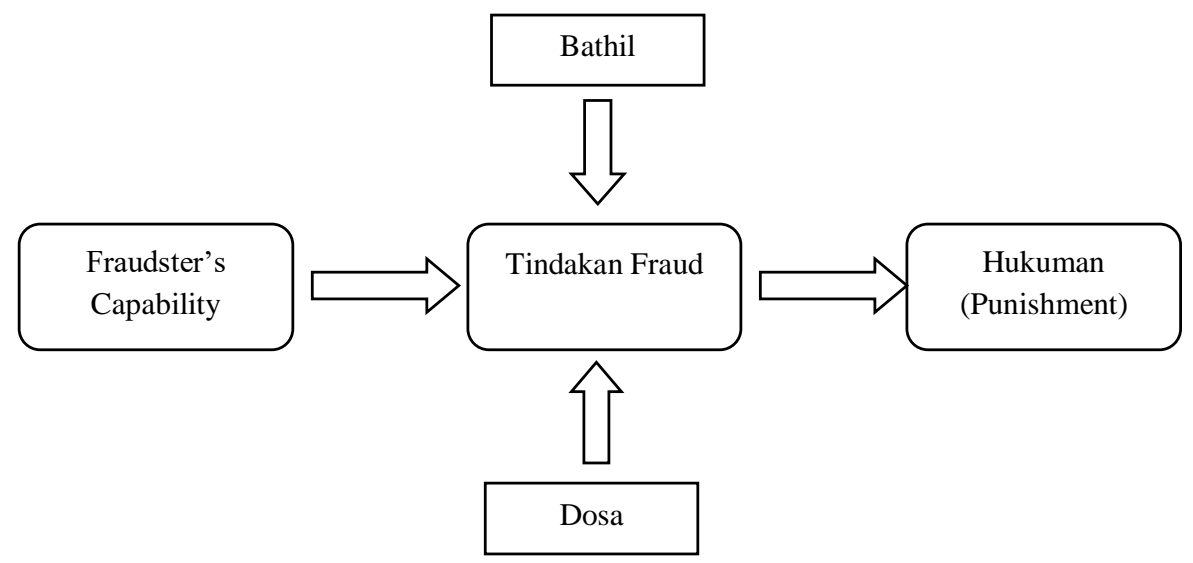

Gambar 3

Fraud dalam Sudut Pandang Islam

Sumber : data penelitian, diolah (2019) 


\section{Memanfaatkan Kepercayaan Nasabah demi Keuntungan Pribadi}

Tindakan fraud yang telah dilakukan oleh pelaku T dan B pada BSX dapat berhasil karena pelaku memanfaatkan kepercayaan nasabah. Kepercayaan nasabah ini telah menjadi suatu peluang (opportunity) yang memberikan kesempatan bagi para pelaku untuk melakukan tindakan fraud. Hal ini didasarkan pada hasil wawancara yang telah dilakukan oleh pelaku T sebagai berikut:

"Salah seorang kerabat istri saya menjadi nasabah priority. Atas banyaknya rekening beliau yang tersebar di beberapa bank, seringkali beliau nggak peduli dengan jumlah tabungannya yang terdapat di Bank X. Hal itu menjadi celah bagiku untuk melakukan fraud. Apalagi tanda tangan beliau juga mudah untuk ditiru. Selain itu, sebagai frontliner saya memiliki cadangan copy KTP beberapa nasabah priority. Hal ini untuk mempermudah pekerjaan agar dapat memberikan layanan prima bagi nasabah, sehingga pada saat nasabah priority bertransaksi, kami tidak perlu meminta copy KTP mereka untuk konfirmasi. Dari situ, saya dapat dengan mudah memalsukan tanda tangan beliau pada form penarikan."

Hasil wawancara diatas menunjukkan bahwa tindakan fraud yang dilakukan oleh pelaku $\mathrm{T}$ dan $\mathrm{B}$ dapat terjadi karena adanya beberapa alasan yaitu (1) adanya kealphaan nasabah atas jumlah saldo yang dimiliki dan (2) adanya kepemilikan dokumen nasabah yang berada dibawah kendali pelaku. Tuanakotta (2013:46) menjelaskan bahwa opportunity pada fraud adalah berhubungan dengan peluang dari pelaku fraud dalam melakukan kecurangan. Dua kondisi ini kemudian menyebabkan pelaku dengan leluasa melakukan aksi fraud atas rekening nasabah yang bersangkutan. Pelaku T yang mengetahui bahwa nasabah memiliki banyak rekening di beberapa bank langsung membuat suatu asumsi adanya kelalaian dalam menghafal jumlah saldo yang ada pada setiap rekening yang dimiliki. Selain itu, pelaku $\mathrm{T}$ juga semakin yakin untuk melakukan tindakan fraud karena pelaku $\mathrm{T}$ memiliki dokumen-dokumen pendukung yang dibutuhkan seperti copy KTP nasabah dan tanda tangan pelaku yang mudah ditiru.

Adanya peluang (opportunity) terjadinya fraud pada BSX ini pada dasarnya juga diakibatkan oleh adanya kekurangan pada pengendalian internal perusahaan. Tedjasukma (2012:50) menjelaskan bahwa peluang yang mengakibatkan pelaku bebas melakukan fraud dapat disebabkan karena kontrol yang lemah, ketidakdisiplinan, akses informasi yang lemah, mekanisme audit yang lemah, dan sikap apatis. Kasus fraud yang terjadi di BSX ini sebenarnya dapat terjadi karena kontrol terhadap dokumendokumen penting seperti copy KTP, tanda tangan, dan lainnya milik nasabah tidak terlindungi dengan baik yang pada akhirnya menyebabkan munculnya peluang bagi pelaku untuk melakukan fraud.

Tindakan penggunaan dokumen penting oleh pelaku T dan B untuk tujuan tindak kecurangan (fraud) ini pada dasarnya sudah sangat tidak sesuai dengan syariah Islam. Hal ini dikarenakan pelaku T menggunakan dokumen tersebut tanpa sepengetahuan dan seizin pemiliknya untuk mengambil harta milik nasabah, sehingga menyebabkan kerugian bagi nasabah. Tindakan pelaku T dan $B$ selain telah melanggar ajaran syariat Islam karena merampas dan menggunakan barang milik orang lain tanpa izin juga telah melanggar ajaran Islam karena tujuan tindakan yang dilakukan adalah untuk mencuri harta dari nasabah. Tindakan pelaku tersebut telah jelas merupakan tindakan memakan harta sesama melalui jalan yang batil.

\section{Keakraban yang Berujung pada Kecurangan}

Kejadian fraud yang terjadi di BSX dapat terjadi karena keakraban yang terjadi antara pelaku $\mathrm{T}$ sebagai frontliner dan pelaku $\mathrm{B}$ sebagai manajer. Hal ini dapat diketahui dari hasil wawancara yang telah dilakukan oleh pelaku T dan B sebagai berikut: 


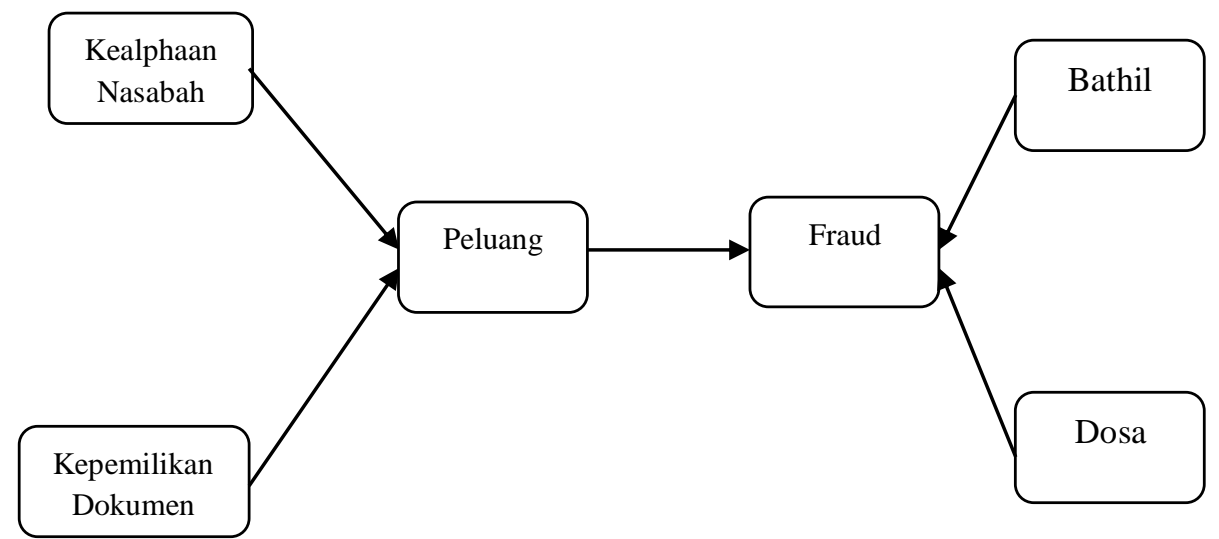

\section{Gambar 4 \\ Sumber : data penelitian, diolah (2019) \\ Keterkaitan Opportunity dan Fraud}

\section{Pelaku T:}

“....Masa jabatan yang lama menjadikan saya sangat dekat dengan pak $B$, sebagai atasan langsung saya. Selain masa jabatan yang lama, saya juga menyadari bahwa kami memiliki gaya hidup yang sama. Atas kedekatan ini, pak B menjadikan saya sebagai orang kepercayaannya. Hal ini dapat kamu lihat sendiri, bagaimana pak B mempercayakan user serta password otorisasinya hanya kepada saya."

"...Sejak awal kedatangan beliau, saya sudah melakukan pendekatan. Biasalah, tujuan saya hanya agar karir saya disini mulus. Karena beliau bukan penduduk asli sini, saya menunjukkan kepada beliau apa saja yang terdapat di sini...."

\section{Pelaku B:}

“....Sejak awal kedatangan saya di BSX, saya dekat dengan mas T. Saya pikir, karena mas $T$ sudah lama menduduki posisinya sebagai seorang frontliner, dia pasti sangat paham dengan seluk-beluk operasional di BSX, terutama untuk bagian frontliner..."

Hasil wawancara diatas tersebut menunjukkan bahwa telah terjadi kedekatan secara personal antara pelaku T dan B. Kedekatan personal antara pelaku $\mathrm{T}$ dan B juga telah diakui oleh kedua pihak. Kedekatan antara pelaku T dan B berdasarkan hasil wawancara disebabkan adanya upaya dari pelaku $\mathrm{T}$ untuk mendekati pelaku B dengan tujuan untuk membuat karirnya menjadi lebih baik. Selain itu, pelaku B merasa bahwa kedekatan antara dirinya dengan pelaku $\mathrm{T}$ karena pelaku T merupakan frontliner "senior" di BSX dan pelaku B menganggap pelaku T mampu membantu dirinya untuk memahami dan mengenal daerah domisili. Dengan demikian, pada akhirnya terjadilah kedekatan antara pelaku $\mathrm{T}$ dan $\mathrm{B}$. Hal ini sejalan dengan temuan Dinata, et al (2018) yang menegaskan adanya hubungan yang signifikan antara keeratan hubungan di antara pelaku fraud dengan tindakan bekerjasama dalam melakukan kecurangan.

Kedekatan yang terjadi antara pelaku T dan B akhirnya membuat keinginan, dorongan, dan hasrat dari pelaku $\mathrm{T}$ untuk melakukan kecurangan. Kedekatan antara pelaku $\mathrm{T}$ dan $\mathrm{B}$ ini juga sebenarnya pada awalnya sudah diikuti dengan personal integrity yang tidak baik dari pelaku $\mathrm{T}$. Pelaku T sudah memiliki niat jelek dibalik maksud kedekatan dirinya dengan pelaku B. Kedekatan antara pelaku $\mathrm{T}$ dan $\mathrm{B}$ ini dapat memicu munculnya niat melakukan kecurangan karena pelaku B telah sangat percaya kepada pelaku $\mathrm{T}$ sampai-sampai pelaku $\mathrm{T}$ memiliki otorisasi dan user serta password pelaku B. 
Kondisi yang terjadi pada kasus kecurangan oleh pelaku T dan B di BSX ini menandakan bahwa personal integrity yang dimiliki oleh $\mathrm{T}$ dan $\mathrm{B}$ tidak baik. Integritas dalam dunia kerja berkaitan dengan perlaku etis, moral, dan kinerja. Integritas personal menentukan tingkat kinerja seseorang dalam dunia kerja. Integritas berasal dari kata "integrated" yang memiliki makna bagian dari karakter dan keterampilan yang ada dalam diri seseorang yang diwujudkan dalam bentuk keputusan-keputusan dan tindakan (Lee, 2006). Hal ini menunjukkan bahwa jika keputusan dan tindakan seseorang itu melanggar aturan, maka dapat diartikan bahwa integritasnya pun tidak baik. Sebaliknya jika keputusan dan tindakan seseorang bagus maka integritasnya pun juga bagus.

Oleh karena itu, dapat di- simpulkan bahwa tindak kecurangan yang dilakukan oleh $\mathrm{T}$ dan $\mathrm{B}$ akibat kedekatan yang terjadi antara keduanya disebabkan karena integritas personal kedua orang tersebut tidak baik. Hal ini dikarenakan keduanya telah mengenyampingkan kinerja, moral, dan perilaku etika untuk melakukan kecurangan hanya dikarenakan keduanya memiliki kedekatan.

\section{Sifat Skeptisme yang Berujung pada Terungkapnya Kasus Fraud}

Seluruh perbuatan yang tidak baik pasti pada akhirnya akan terungkap juga. Demikian juga terkait kasus fraud yang dilakukan oleh T dan B pada BSX. Hal ini dikarenakan pada dasarnya ketika fraud ini dilakukan oleh pelaku $\mathrm{T}$ dan $\mathrm{B}$ sudah dicurigai oleh informan I dan auditor internal yang ada di bank. Informan I dan auditor internal merasa curiga atas fraud yang terjadi akibat adanya kejanggalan yang terjadi. Berikut adalah hasil wawancara yang menunjukkan adanya kecurigaan dari kedua informan tersebut:

Informan I:

“...Siangnya pak B panggil mbak N. Pak

$B$ kasih form setoran tunai sama uang tunai ke mbak N. Aku nggak sengaja tanya ke pak B, bukannya itu uang tunai yang tadi ditarik nasabah priority? Soalnya aku liat uang itu sudah ada ban uangnya. Ban uang itu ada parafku, artinya kan aku yang ngeban uang itu. Terus kata pak B, memang iya. Katanya itu uang hasil transaksi jual beli mobil sama nasabah priority itu. Tapi aku sama mbak $N$ agak nggak percaya sih. Pak B kan nggak punya mobil sendiri. Beliau kan biasa pake mobil kantor kalo berangkat sama pulang kerja. Dari situ, aku sama mbak $N$ inisiatif lapor ke auditor internal...."

Informan Auditor Internal (A):

"...Saat itu saya sebagai auditor internal cabang mendapat laporan atas transaksi mencurigakan yang melibatkan salah seorang manajer. I dan $N$ yang melaporkannya sendiri. Selanjutnya, saya selidiki kebenaran transaksi tersebut. Hasilnya saya kirimkan ke auditor pusat sebagai laporan pekerjaan saya. Dalam proses selanjutnya, saya sebagai auditor cabang harus bekerjasama dengan auditor pusat untuk menuntaskan kasus ini. Sebenarnya telah lama saya mencurigai gerak-gerik keduanya. Menurut saya, gaya hidup mereka melebihi kewajaran dari gaji yang mereka dapat, seringnya mereka tiba di kantor lebih awal dan pulang paling akhir, serta mereka sangat jarang mengambil hak cuti karyawan. Bahkan saat mereka sakit sekalipun..."

Hasil wawancara tersebut menunjukkan bahwa kecurangan yang dilakukan oleh $\mathrm{T}$ dan B telah menimbulkan kecurigaan dari rekan pelaku $\mathrm{T}$ dan auditor internal karena adanya suatu yang tidak wajar. Teman kerja pelaku $\mathrm{T}$ mencurigai tindakan fraud dari adanya transaksi yang aneh, sedangkan auditor internal mencurigai terjadinya fraud sejak adanya gejala fraud yang terjadi pada para pelaku seperti gaya hidup dan kebiasaan yang tidak wajar dari pelaku. Hal ini lah yang pada akhirnya membuat tindakan fraud tersebut menjadi suatu 
laporan untuk selanjutnya diselidiki lebih lanjut. Kecurigaan yang dimiliki oleh auditor internal pada hal ini merupakan suatu sikap yang sudah benar. Seorang auditor memang dituntut untuk memiliki suatu bentuk sikap yang waspada (skeptisisme) dalam menyikapi potensi kecurangan (Fullerton dan Durtschi, 2004; Noviyanti, 2008; Putri et.al, 2017; Larasati dan Puspitasari, 2019). Sikap skeptis auditor merupakan sikap auditor yang tidak mudah percaya pada sesuatu dan melakukan penilaian kritis pada bukti audit untuk mengambil suatu keputusan didasarkan pada keahlian yang dimiliki (Suraida, 2005). Tindakan yang dilakukan oleh auditor internal pada BSX pada kasus fraud ini sudah menunjukkan adanya sifat skeptisme yang baik, dimana auditor tersebut tidak langsung mempercayai adanya laporan yang diterima dan melakukan koordinasi dengan auditor internal pusat serta melakukan penyeledikan lebih dalam atas kebenaran yang sesungguhnya. Dengan demikian, pada akhirnya kasus fraud ini bisa terungkap kebenarannya.

Kecurigaan dari teman kerja pelaku $\mathrm{T}$ dan auditor internal ini juga menunjukkan adanya kewaspadaan dan kehati-hatian dalam bertindak. Teman kerja pelaku T yang berinisiatif melakukan pelaporan kepada auditor internal dan auditor internal melakukan penyeledikan lebih dalam atas laporan yang diterima. Sikap kewaspadaan dan kehati-hatian dari dua informan tersebut sesuai dengan apa yang telah dijelaskan pada Al-Qur'an sebagai berikut:

"Dan taatlah kamu kepada Allah dan taatlah kamu kepada Rasul-(Nya) dan berhati-hatilah. Jika kamu berpaling, maka ketahuilah bahwa sesungguhnya kewajiban Rasul Kami, hanyalah menyampaikan (amanat Allah) dengan terang" (Q.S. Al-Maidah ayat 92)

Menurut tafsir Al-Misbah (Shihab, 2017) disebutkan bahwa kita harus menaati perintah Allah dan perintah Rasul-Nya pada setiap hal yang disampaikan Allah. Menjauhi apa-apa yang memungkinkan membuat kita mendapat siksaan jika melanggar.
Tidak ada alasan bagi manusia setelah Rasulullah menjelaskan hukuman orangorang yang melanggar. Tugas Rasul hanyalah menyampaikan hukum-hukum Allah dan menjelaskannya dengan sempurna.

Tindakan dari kedua informan yaitu teman kerja $\mathrm{T}$ dan auditor internal telah sesuai dengan ayat tersebut. Mereka mengetahui bahwa terjadi suatu yang salah pada transaksi yang dilakukan oleh pelaku T dan B. Oleh karena itu, teman rekan kerja $\mathrm{T}$ berhati-hati agar tidak ikut terjebak dalam kasus tersebut dengan membuat laporan kepada auditor internal. Hal ini akhirnya juga membuat auditor internal juga melakukan suatu penyeledikan lanjut untuk secara berhati-hati dalam mengambil simpulan atas laporan yang diterima.

\section{SIMPULAN DAN SARAN}

Pemaparan yang telah dijelaskan pada pembahasan dijelaskan bahwa konsep The New Fraud Triangle Model mampu menjelaskan fenomena kecurangan yang terjadi melalui empat unsur. Pertama, tindakan fraud yang dilakukan oleh pelaku $\mathrm{T}$ dan $\mathrm{B}$ diakibatkan oleh adanya motivasi dari pelaku. Pelaku melakukan tindak kecurangan dikarenakan gaya hidup kedua pelaku yang melebihi dari penghasilan yang diterima, sehingga pelaku memiliki niat untuk melakukan fraud. Kedua, tindakan fraud yang dilakukan oleh pelaku $\mathrm{T}$ dan $\mathrm{B}$ diakibatkan oleh adanya capability. Pelaku T dan B yang memanfaatkan posisi pekerjaan yang dimiliki mampu melakukan fraud karena tugas dan wewenang yang dimiliki membuat tindakan fraud yang dilakukan menjadi lebih mudah dan leluasa. Ketiga, tindakan fraud yang terjadi diakibatkan oleh adanya peluang yang dimiliki. Nasabah yang telah mempercayakan saldo rekening dan dokumen yang dimiliki kepada pihak bank membuat pelaku $\mathrm{T}$ dan $\mathrm{B}$ memiliki peluang untuk melakukan fraud tanpa diketahui oleh nasabah yang bersangkutan. Keempat, tindak kecurangan juga terjadi karena personal integrity yang tidak bagus dari kedua pelaku. Hal ini ditunjukkan dari 
pemanfaatan kedekatan antar personal di pihak $\mathrm{T}$ dan $\mathrm{B}$ yang dijadikan sebagai modal untuk melakukan tindak kecurangan.

Tindakan kecurangan (fraud) yang terjadi di BSX dapat dicegah melalui beberapa cara. Pertama, secara formal tindak kecurangan dapat dicegah dengan menerapkan strategi anti fraud yang sesuai dengan Surat Edaran Bank Indonesia (SEBI) No. 13/28/DPNP tentang penerapan strategi anti fraud bagi bank umum. Strategi anti fraud ini terdiri dari 4 pilar yaitu pencegahan, pendeteksian, investigasi, pelaporan, sanksi, dan pemantauan serta evaluasi dan tindak lanjut. Kedua, secara intrapersonal tindakan kecurangan ini dapat dicegah dengan memperbaiki karakter dan hati melalui olah batin. Olah batin dapat dilakukan dengan cara mendekatkan diri kepada Allah SWT.

Adapun keterbatasan dan saran yang ada pada penelitian ini adalah sebagai berikut, pertama, penelitian ini belum bisa menyajikan bukti terkait kasus fraud yang terjadi karena dibatasi oleh kewenangan untuk mempublikasikan data tentang kasus hukum yang menyangkut nama perusahaan. Kedua, penelitian ini memiliki keterbatasan dalam memperoleh informasi terkait terjadinya kasus kecurangan. Hal ini dikarenakan beberapa pihak masih sulit untuk dimintai keterangan terkait kasus ini dan memilih untuk bungkam.

Berdasarkan keterbatasan atas hasil penelitian ini, penelitian selanjutnya sebisa mungkin untuk menggunakan sumber dokumen lain yang terkait tentang kasus yang dapat menggantikan dokumen bukti untuk membuat penelitian menjadi lebih menarik. Berikutnya penelitian selanjutnya diharapkan peneliti dapat menentukan terlebih dahulu pihak-pihak yang mampu memberikan informasi secara memadai atau tidak.

\section{DAFTAR PUSTAKA}

Al-Quran Terjemahan. 2015. Departemen Agama RI. CV Darus Sunnah. Bandung.
Alfian, N. 2016. Nilai-Nilai Islam Dalam Upaya Pencegahan Fraud. AKTIVA Jurnal Akuntansi dan Investasi 1(2): 205218.

Cressey, D. R. 1950. The Criminal Violation of Financial Trust. American Sociological Review. 15(6): 738-743.

Dinata, R. O., G. Irianto, dan A. D. Mulawarman. 2018. Menyingkap Budaya Penyebab Fraud: Studi Etnografi di Badan Usaha Milik Negara. Jurnal Economia 14(1): 66-88.

Fauziah, N. 2019. Analisis Kecurangan Dalam Timbangan Sembako Menurut Perspektif Hukum Islam Di Pasar Pendidikan Krakatau Medan. Skripsi. Program Studi Manajemen Bisnis Syariah. Medan.

Fullerton, R. dan C. Durtschi. 2004. The Effect of Professional Skepticism on the Fraud Detection Skills of Internal Auditors. $h$ ttps://ssrn.com/abstract=617062.

Hadi, S. 2016. Pemeriksaan Keabsahan Data Penelitian Kualitatif Pada Skripsi. Jurnal Ilmu Pendidikan. 22(1): 74-79.

Hadits riwayat Bukhari No. 1472.

Hadits riwayat Bukhari No. 6439.

Hadits riwayat Muslim No. 1048.

Hidayati, M. N. 2008. Dewan Pengawas Syariah dalam Sistem Hukum Perbankan: Studi tentang Pengawasan Bank Berlandaskan pada Prinsip-Prinsip Islam. Lex Jurnalica, 6(1).

Kartika, U. 2015. Orang Dalam "Bermain", Bank Syariah Mandiri Dibobol Rp 50 Miliar.

https://megapolitan.kompas.com/read/2015/ 02/02/18582981/Orang.Dalam.Bermain.Ba nk.Syariah.Mandiri.Dibobol.Rp.50.Miliar.

Diakses Tanggal 15 September 2018.

Ibrahim, S. S., N. C. Man, dan A. H. Mohd Noor. 2013. Fraud: An Islamic Perspective. International Conference on Financial Criminology. In The 5th International Conference on Financial Criminology (ICFC). Malaysia.

Kassem, R. dan A. Higson. 2012. The New Fraud Triangle Model. Journal of 
Emerging Trends in Economics and Management Sciences 3(3): 191-195.

Kennedy, P. S. J. dan S. L. Siregar. 2017. Analisa Perilaku Fraud Tipologi Korupsi Ditinjau Dari Demografi Pelaku. Ikraith-Humaniora 1(2): 86-96.

Kurrohman, T. 2010. Menyingkap "Malpraktik" Tatakelola Resiko Etika Pada PT. "G" Di Jawa Timur. Jurnal Akuntansi Universitas Jember 8(2): 40-68.

Larasati, D. dan W. Puspitasari. 2019. Pengaruh Pengalaman, Independensi, Skeptisisme Profesional Auditor, Penerapan Etika, dan Beban Kerja Terhadap Kemampuan Auditor Dalam Mendeteksi Kecurangan. Jurnal Akuntansi Trisakti 6(1): 31-42.

Lee, S. A. 2006. Authentic Leadership And Behavioral Integrity As Drivers Of Follower Commitment And Performance. Journal of Financial Planning 19(8).

Lister, L. M. 2007. A Practial Approach to Fraud Risk.

https://www.researchgate.net/publication/2 88030790_A_practical_approach_to_fraud_ risk. Diakses pada 15 September 2018.

Meliana dan T. R. Hartono. 2019. Fraud Perbankan Indonesia: Studi Eksplorasi. Prosiding Seminar Nasional Pakar ke 2 Tahun 2019: 2.52.1-2.52.7.

Mukhlishin, A. dan A. Suhendri. 2018. Kajian Kritis Terhadap Kebijakan Pemerintah dalam Pengembangan Bank Syari'ah di Indonesia. Human Falah 5(2): 238-248.

Noviyanti, S. 2008. Skeptisme Profesional Auditor Dalam Mendeteksi Kecurangan. Jurnal Akuntansi dan Keuangan Indonesia 5(1): 102-125.

Nugraheni, N. K. dan H. Triatmoko. 2017. Analisis Faktor-Faktor yang Mempengaruhi Terjadinya Financial Statement Fraud: Perspektif Diamond Fraud Theory (Studi Pada Perusahaan Perbankan yang Terdaftar di Bursa Efek Indonesia Periode 2014-2016). Jurnal Akuntansi dan Auditing 14(2): 118-143.

Putri, K. M. D., D. G. Wirama, dan I. P. Sudana. 2017. Pengaruh Fraud Audit
Training, Skeptisisme Profesional, dan Audit Tenure Pada Kemampuan Auditor Dalam Mendeteksi Kecurangan. E-Jurnal Ekonomi dan Bisnis Universitas Udayana 6(11): 3795-3822.

Rahardjo, M. 2017. Studi Kasus dalam Penelitian Kualitatif: Konsep dan Prosedurnya. Universitas Islam Negeri Maulana Malik Ibrahim Malang.

Rahman, M. F. 2018. Hakekat dan BatasanBatasan Gharar Dalam Transaksi Maliyah. SALAM; Jurnal Sosial \& Budaya Syar-I 5(3): 255-278.

Ristianingsih, I. 2017. Telaah Konsep Fraud Diamond Theory Dalam Mendeteksi Perilaku Fraud di Perguruan Tinggi. Prosiding Seminar Nasional dan Call For Paper Ekonomi dan Bisnis: 128-139.

Republika. 2013. Fraud Gerus Laba BSM. https://www.republika.co.id/berita/ekonomi/ keuangan/13/10/31/mvj8sn-fraud-geruslaba-bsm. Diakses Tanggal 15 September 2018.

Rustiarini, N. W., N. N. A. Suryandari, dan I. K. S. Nova. 2017. Red Flags and Fraud Prevention on Rural Banks. Buletin Ekonomi Moneter dan Perbankan 19(2): 177-206.

Said, J., M. M. Alam, M. Ramli, dan M. Rafidi. 2017. Integrating ethical values into fraud triangle theory in assessing employee fraud: Evidence from the Malaysian banking industry. Journal of International Studies 10(2): 170-184.

Sayekti, N. W. dan A. T. Mauleny. 2013. Analisis Kinerja Perbankan Syariah di Indonesia: Pra dan Pasca UndangUndang Nomor 21 Tahun 2008 Tentang Perbankan Syariah. Jurnal Ekonomi dan Kebijakan Publik 4(1): 27-38.

Shihab, M. Q. 2017. Tafsir Al-Misbah. Lentera Hati. Tangerang.

Siregar, S. L. 2017. Literature Review: Perilaku Korupsi dan Penyebabnya. Fundamental Management Journal 2(1): 47-56.

Sujeewa, G. M. M, M. S. A. Yajid, A. Khatibi, S. M. F. Azam, dan I. Dharmaratne. 2018. The New Fraud Triangle TheoryIntegrating Ethical Values of Employees. 
46 Ekuitas: Jurnal Ekonomi dan Keuangan - Volume 4, Nomor 1, Maret 2020 : 21 - 46

International Journal of Business, Economics and Law 16(5): 52-57.

Surat Edaran Bank Indonesia Nomor 13/28/DPNP tentang Penerapan Strategi Anti Fraud bagi Bank Umum. 9 Desember 2011. Jakarta.

Tafsir Ibnu Katsir 10 Jilid. Pustaka Imam Syafii. Jakarta.

Tedjasukma, F. N. 2012. Pentingnya Red Flag Bagi Auditor Independen Untuk Mendeteksi Kecurangan Dalam Laporan Keuangan. Berkala Ilmiah Mahasiswa Akuntansi 1(1): 47-51.

Tuanakotta, T. M. 2013. Audit Berbasis ISA (International Standards on Auditing). Salemba Empat. Jakarta.

Undang-Undang Republik Indonesia Nomor 21 Tahun 2008. Perbankan Syariah. 16 Juli 2008. Lembaran Negara Republik Indonesia Tahun 2008 Nomor 94. Jakarta.

Utari, I. S. 2011. Faktor Penyebab Korupsi, Pendidikan Anti Korupsi Untuk Perguruan Tinggi. Kementrian P\&K. Direktorat Jenderal Perguruan Tinggi. Pendidikan Anti-Korupsi untuk Perguruan Tinggi, 37-51.
Vona, L. W. 2008. Fraud Risk Assessment: Building a Fraud Audit Program. John Wiley \& Sons, Inc. Canada.

Wahyuningtyas, F. 2016. Analisis ElemenElemen Fraud Diamond Sebagai Determinan Finansial Statement Fraud pada Perusahaan Perbankan di Indonesia. Tesis. Universitas Airlangga. Surabaya.

Wolfe, D. T. dan D. Hermanson. 2004. The Fraud Diamond: Considering the Four Elements of Fraud. CPA Journal 74(12): 38-42.

Yesiariani, M. dan I. Rahayu. 2017. Deteksi Financial Statement Fraud: Pengujian dengan Fraud Diamond. Jurnal Akuntansi dan Auditing Indonesia 21(1): 49-60.

Yurmaini. 2017. Kecurangan Akuntansi (Fraud Accounting) Dalam Perspektif Islam. Jurnal Akuntansi dan Bisnis 3(1): 93-104.

Zuberi, O. dan S. Mzenzi. 2019. Analysis of Employee and Management Fraud in Tanzania. Journal of Financial Crime 26(2): 412-431. 